PNL-10173

UC-600

\title{
Ammonia in Simulated Hanford Double-Shell Tank Wastes: Solubility and Effects on Surface Tension
}

J. D. Norton

L. R. Pederson

September 1994

Prepared for

the U.S. Department of Energy

under Contract DE-AC06-76RLO 1830

Pacific Northwest Laboratory

Richland, Washington 99352

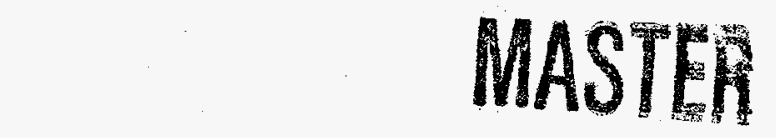




\section{DISCLAIMER}

This report was prepared as an account of work sponsored by an agency of the United States Government. Neither the United States Government nor any agency thereof, nor any of their employees, make any warranty, express or implied, or assumes any legal liability or responsibility for the accuracy, completeness, or usefulness of any information, apparatus, product, or process disclosed, or represents that its use would not infringe privately owned rights. Reference herein to any specific commercial product, process, or service by trade name, trademark, manufacturer, or otherwise does not necessarily constitute or imply its endorsement, recommendation, or favoring by the United States Government or any agency thereof. The views and opinions of authors expressed herein do not necessarily state or reflect those of the United States Government or any agency thereof. 


\section{DISCLAIMER}

Portions of this document may be illegible in electronic image products. Images are produced from the best available original document. 


\section{Executive Summary}

Ammonia solubilities in simulated Hanford double-shell tank wastes and in sodium hydroxide solutions have been determined as a function of electrolyte concentration and temperature, from 25 to $70^{\circ} \mathrm{C}$. Expressions for Henry's Law constants were derived from these data. Where possible, experimentally determined Henry's Law constants were compared with those calculated from ion interaction parameters obtained from the literature. The effect of ammonia on the liquid/vapor surface tension of simulated wastes has also been evaluated.

Ammonia solubilities were measured using an isoteniscope that was modified to prevent the selective loss of condensable vapors. The apparatus consisted of a sample vessel, a U-tube partially filled with pentadecane, a septum for injection of aqueous ammonia into the sample vessel, a vacuum pump, nitrogen gas inlet, a mercury manometer, and associated valves. The purpose of the U-tube containing pentadecane was to isolate the temperature-controlled sample vessel from the mercury manometer. Pentadecane is well-suited for this purpose because the liquid exhibits a low vapor pressure, dissolves negligible quantities of ammonia, and is non-reactive with ammonia in the temperature range of interest.

For the concentrated waste simulant mixtures, ammonia partial pressures were considerably higher than found for dilute solutions containing identical concentrations of aqueous ammonia. This effect was most pronounced for the simulant SY1-SIM-91A, a slurry. For sodium hydroxide solutions, ammonia vapor pressures rose steadily with increased sodium hydroxide concentration, for a fixed aqueous ammonia concentration. Experimentally determined ammonia partial pressures are in reasonably good agreement with those calculated using Pitzer interaction coefficients.

Expressions for Henry's Law constants for ammonia solubilities in simulated waste mixtures were determined. For the simulant SY1-SIM-93B, a homogeneous simulant, Henry's Law constants are in units of moles ammonia per kilogram water per atmosphere ammonia:

$$
\ln \left(\mathrm{K}_{\mathrm{H}(\mathrm{SY} 1-\mathrm{SIM}-93 \mathrm{~B})}\right)=-7.357+3330.1 / \mathrm{T}(\mathrm{K})-0.002139 \mathrm{~T}(\mathrm{~K})
$$

For the simulant SY1-SIM-91A, a heterogeneous (slurry) simulant, the expression is:

$$
\ln \left(\mathrm{K}_{\mathrm{II}(\mathrm{SY} 1-\mathrm{SIM}-91 \mathrm{~A})}\right)=-7.577+2571.3 / \mathrm{T}(\mathrm{K})+0.003076 \mathrm{~T}(\mathrm{~K})
$$

Aqueous ammonia concentrations in Tank 241-SY-101 can be estimated, based on the Henry's Law constants determined for simulant SY1-SIM-91A, the composition of gases released from that tank, the fraction of water present, and temperature. If ammonia represents 11 mole percent of the gases retained in the non-convective layer at an average pressure of 2 atmospheres, U.S. Department of Energy (1994), the water content of the wastes is 40 weight percent, and if the temperature is $50^{\circ} \mathrm{C}$, the concentration of aqueous ammonia in the non-convecting layer is estimated at 0.6 weight percent. Higher temperatures and lower water content in the non-convecting layer lead to smaller estimates for the aqueous ammonia content of the wastes. For example, if the water content in the non-convecting layer was 30 weight percent and the temperature was $60^{\circ} \mathrm{C}$, an aqueous ammonia concentration of 0.37 weight percent is estimated. This estimate would also be lowered if the composition of gases released from the non-convecting layer was not prescrved as the gases procecded to the top of the wastes. Gas bubbles that rise slowly to the top of the wastes will extract ammonia gas from the liquid to re-establish the equilibrium ammonia partial pressure as the overall pressure falls, resulting in a higher mole fraction of ammonia than those released instantaneously. 
Liquid/vapor surface tension values are needed for modelling waste behavior. Surface tension is one of the parameters that determines the morphology of gas bubbles retained in tank wastes and the response of gas bubblc/solid particle combinations to acoustic waves. In these studies, the surface tension of simulated waste mixtures was determined using the maximum bubble pressure method originally described by Sugden (1922). In this method, twin capillary tubes with dissimilar diameters are inserted to identical depths into the liquid to be evaluated. Maximum pressures required to form and release a gas bubble are recorded, from which surface tension values are calculated. Key advantages of this method include being independent of liquid/solid (capillary tube) contact angle, as long as the contact angle is smaller than $90^{\circ} \mathrm{C}$, being amenable to measurements involving corrosive liquids, and being relatively insensitive to liquid density.

Ammonia was found to be the most surface-active of the components known to be present in actual tank wastes. A 1-weight percent addition of aqueous ammonia lowered the surface tension of the simulant SY1-SIM-91A at $50^{\circ} \mathrm{C}$ from approximately 100 dynes $/ \mathrm{cm}$ to less than 70 dynes $/ \mathrm{cm}$, which is similar to the surface tension of pure water at that temperature. Similar but smaller effects were noted for the homogeneous simulant SY1-SIM-93B. In the absence of ammonia, surface tension values are well-known to be raised by the presence of dissolved electrolytes. Simulant surface tension values were not measurably affected by the addition of sodium citrate, sodium EDTA, sodium HEDTA, sodium formate, or glycine. Measured surface tension were also insensitive to the identity of the gas used to create bubbles. Essentially identical results were obtained using oxygen, hydrogen, nitrogen, nitrous oxide, and methane. 


\section{Contents}

Executive Summary $\ldots \ldots \ldots \ldots \ldots \ldots \ldots \ldots \ldots \ldots \ldots \ldots \ldots \ldots \ldots \ldots \ldots$ iii

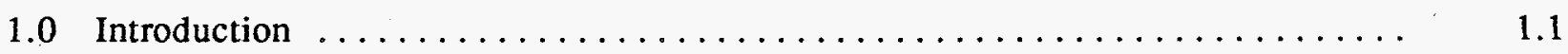

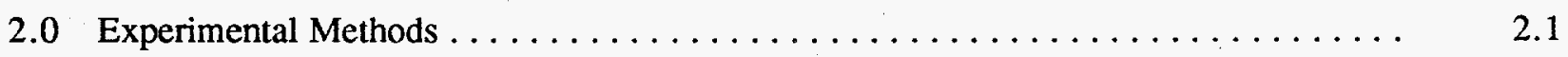

2.1 Waste Simulant Compositions $\ldots \ldots \ldots \ldots \ldots \ldots \ldots \ldots \ldots \ldots \ldots \ldots \ldots \ldots \ldots$

2.2 Solubility Measurements $\ldots \ldots \ldots \ldots \ldots \ldots \ldots \ldots \ldots \ldots \ldots \ldots \ldots \ldots \ldots \ldots$

2.3 Surface Tension Measurements $\ldots \ldots \ldots \ldots \ldots \ldots \ldots \ldots \ldots \ldots \ldots \ldots$

3.0 Ammonia Solubility Determinations in Sodium Hydroxide Solutions and in Waste Simulant Mixtures ........................... 3.1

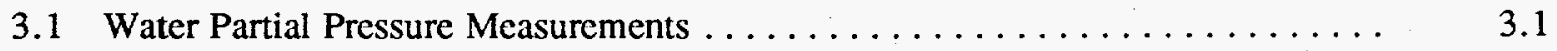

3.2 Ammonia Partial Pressure and Henry's Law Constants . . . . . . . . . 3.3

3.3 Comparison to Ion Interaction Model $\ldots \ldots \ldots \ldots \ldots \ldots \ldots \ldots \ldots$

3.4 Estimation of Aqueous Ammonia Content in Tank $241-S Y-101 \ldots \ldots \ldots$

4.0 Surface Tension by the Maximum Bubble Pressure Method $\ldots \ldots \ldots \ldots \ldots \ldots .1$

4.1 Surface Tension of Sodium Hydroxide, Sodium Nitrate, and Simulant

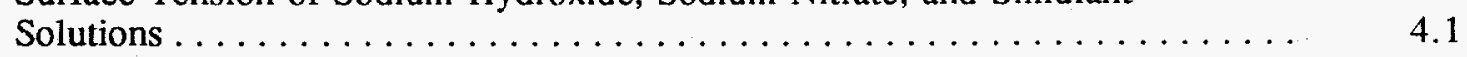

4.2 Effect of Ammonia on the Surface Tension of Simulated Wastes . . . . . . . 4.2

4.3 Effect of Added Organics and Effect of Gas Identity on the Surface Tension of Simulated Wastes . . . . . . . . . . . . . . . . . . . .

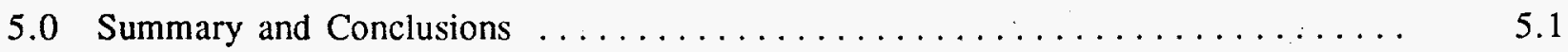

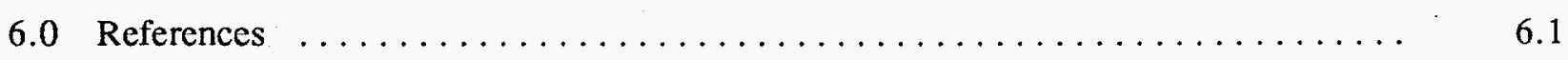

Appendix A - Sodium Hydroxide Solution Partial Vapor Pressures $\ldots \ldots \ldots \ldots \ldots$ A.1

Appendix B - Simulant Partial Pressure $\ldots \ldots \ldots \ldots \ldots \ldots \ldots \ldots \ldots \ldots \ldots \ldots \ldots$

Appendix $\mathrm{C}$ - Surface Tension Results $\ldots \ldots \ldots \ldots \ldots \ldots \ldots \ldots \ldots \ldots \ldots \ldots \ldots$ 


\section{Figures}

1 Schematic of the Isoteniscope Used to Evaluate Ammonia Solubilities in

Electrolyte Solutions . . . . . . . . . . . . . . . . . . . . . .

2 Schematic of the Maximum Bubble Pressure Apparatus Used to Measure the

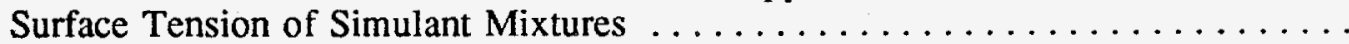

3 Partial Pressure of Water Versus Tempcrature for Sodium Hydroxide Solutions, Corresponding to Data Given in Appendix A, Tables A.1 through A.6 . . . . . . .

4 Partial Pressure of Water Versus Temperature for the Waste Simulants SY1-SIM-93B and SY1-SIM-91A, Corresponding to the Data Given in Appendix B,

Tables B.1 and B.2.

5 Ammonia Partial Pressure Versus Temperature for Sodium Hydroxide Solutions ..

6 Ammonia Partial Pressure Versus Temperature for the Simulant SY1-SIM-93B for Several Aqueous Ammonia Concentrations . . . . . . . . . . . . . .

7 Ammonia Partial Pressure Versus Temperature for the Simulant SY1-SIM-91A ...

8 Henry's Law Constants as a Function of Temperature for Sodium Hydroxide

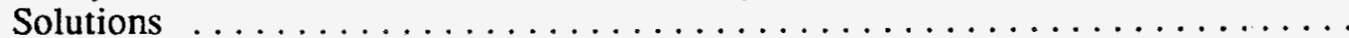

9 Henry's Law Constants as a Function of Temperature for the Waste Simulants SY1-SIM-93B and SY1-SIM-91A . . . . . . . . . . . . . . . . . . .

10 Ratio of the Activity of Ammonia in Simulant Mixtures to that of Ammonia in Water as a Function of Temperature $\ldots \ldots \ldots \ldots \ldots \ldots \ldots \ldots \ldots \ldots$

11 Henry's Law Constants for the Simulant SY1-SIM-93B Versus Temperature, Corresponding to Several Aqueous Ammonia Concentrations . . . . . . . . . . . .

12 Henry's Law Constants for the Simulant SY1-SIM-91A Versus Temperature, Corresponding to Several Aqueous Ammonia Concentrations . . . . . . . . . . . .

13 Comparison of Present Henry's Law Constants for Sodium Hydroxide Solutions with Values Calculated Using the Pitzer Ion Interaction Model . . . . . . .

14 Comparison of Present Henry's Law Constants for Sodium Hydroxide Solutions with Values Calculated from the Data of Wilson et al. (1980) . . . . . . . . . . . . .

15 Comparison of Henry's Law Constants Determined for the Simulant SY1-SIM-93B with Values Calculated from the Pitzer Ion Interaction Model, Using Interaction Parameters Given by Clegg and Brimblecombe (1989) 
16 Estimated Aqueous Ammonia Concentrations in Weight Percent as a Function of Temperature for Several Different Concentrations of Water in the Wastes . . . . . . .

17 Surface Tension of Sodium Hydroxide Solutions as a Function of Temperature ...

18 Surface Tension of Sodium Nitrate Solutions as a Function of Temperature ......

19 Surface Tension of Simulant Mixtures SY1-SIM-91B and SY1-SIM-93A as

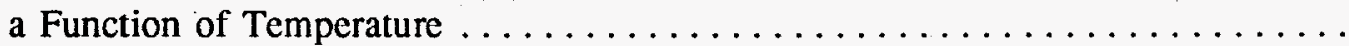

20 Surface Tension of the Simulant SY1-SIM-93B as a Function of Temperature with and Without Aqueous Ammonia Added

21 Surface Tension of the Simulants SY1-SIM-91A and SY1-SIM-93B as a Function of Temperature with and Without Aqueous Ammonia Added ............

22 Surface Tension of Simulant SY1-SIM-93B Containing Various Organic Additives in Concentrations Corresponding to 1.5 Weight Percent Total Organic Carbon .... 


\section{Tables}

1 Concentrations of Components Used in Slurry Simulant SY1-SIM-91 A . . . . . .

2 Concentrations of Components Used in Slurry Simulant SY1-SIM-93B ......

3 Fitted Parameters for Water Partial Pressures as a Function of Temperature for the

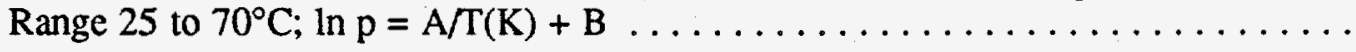

4 Fitted Constants for Henry's Law Constants for Ammonia in Sodium Hydroxide Solutions and in Waste Simulants SY1-SIM-91A and SY1-SIM-93B; $\ln K_{H}=A+$ $\mathrm{B} / \mathrm{T}(\mathrm{K})+\mathrm{CT}(\mathrm{K})$; Temperature Range 25 to $70^{\circ} \mathrm{C}$; Calculated from Tables A.7 through A.12, B.3, and B.7 . . . . . . . . . . . . . . . . . . .

5 Ion Interaction Parameters for Ammonia at $25^{\circ} \mathrm{C}$ Used in Estimating Henry's Law Constants for Simulant SY1-SIM-93B . . . . . . . . . . . . . . . . . .

$6 \quad$ Fitted Constants for Temperature Dependence of Surface Tension of Sodium Hydroxide, Sodium Nitrate, and Waste Simulants SY1-SIM-93B and SY1-SIM$91 \mathrm{~A} ; \gamma=\mathrm{a}-\mathrm{bT}\left({ }^{\circ} \mathrm{C}\right)$; Temperature Range 10 to $80^{\circ} \mathrm{C} \ldots \ldots \ldots \ldots \ldots$

A.1 Water Partial Pressures for 0.50 Molal Sodium Hydroxide Solution Containing 0.00 Molal Aqueous Ammonia . . . . . . . . . . . . . . . . . . .

A.2 Water Partial Pressures for 1.00 Molal Sodium Hydroxide Solution Containing 0.00 Molal Aqueous Ammonia . . . . . . . . . . . . . . . . . .

A.3 Water Partial Pressures for 2.50 Molal Sodium Hydroxide Solution Containing 0.00 Molal Aqueous Ammonia . . . . . . . . . . . . . . . . . . .

A.4 Water Partial Pressures for 3.99 Molal Sodium Hydroxide Solution Containing 0.00 Molal Aqueous Ammonia . . . . . . . . . . . . . . . . . . .

A.5 Water Partial Pressures for 5.67 Molal Sodium Hydroxide Solution Containing 0.00 Molal Aqueous Ammonia . . . . . . . . . . . . . . . . . .

A.6 Water Partial Pressures for 6.95 Molal Sodium Hydroxide Solution Containing 0.00 Molal Aqueous Ammonia . . . . . . . . . . . . . . . . . .

A.7 Ammonia Partial Pressure, Water Partial Pressure, and Calculated Henry's Law Constants for 0.50 Molal Sodium Hydroxide Solution Containing 0.573 Molal Aqueous Ammonia . . . . . . . . . . . . . . . . . . . .

A.8 Ammonia Partial Pressure, Water Partial Pressure, and Calculated Henry's Law Constants for 1.00 Molal Sodium Hydroxide Solution Containing 0.549 Molal Aqueous Ammonia 
A.9 Ammonia Partial Pressure, Water Partial Pressure, and Calculated Henry's Law Constants for 2.50 Molal Sodium Hydroxide Solution Containing 0.643 Molal Aqueous Ammonia . . . . . . . . . . . . . . . . . . . . . . .

A.10 Ammonia Partial Pressure, Water Partial Pressure, and Calculated Henry's Law Constants for 3.99 Molal Sodium Hydroxide Solution Containing 0.616 Molal Aqueous Ammonia . . . . . . . . . . . . . . . . . . . . . . .

A.11 Ammonia Partial Pressure, Water Partial Pressure, and Calculated Henry's Law Constants for 5.47 Molal Sodium Hydroxide Solution Containing 0.741 Molal Aqueous Ammonia . . . . . . . . . . . . . . . . . . . . . .

A.12 Ammonia Partial Pressure, Water Partial Pressure, and Calculated Henry's Law Constants for 6.95 Molal Sodium Hydroxide Solution Containing 0.744 Molal Aqueous Ammonia . . . . . . . . . . . . . . . . . . . . . . .

B.1 Water Partial Pressures for Simulant SY1-SIM-93B (Homogeneous Simulant) Containing 0.000 Molal Aqueous Ammonia . . . . . . . . . . . . . .

B.2 Water Partial Pressures for Simulant SY1-SIM-91A (Slurry) Containing 0.000 Molal Aqueous Ammonia . . . . . . . . . . . . . . . . . . . .

B.3 Ammonia Partial Pressures for Simulant SY1-SIM-93B Containing 0.859 Molal Aqueous Ammonia . . . . . . . . . . . . . . . . . . . .

B.4 Ammonia Partial Pressures for Simulant SY1-SIM-93B Containing 1.519 Molal Aqueous Ammonia . . . . . . . . . . . . . . . . . .

B.5 Ammonia Partial Pressures for Simulant SY1-SIM-93B Containing

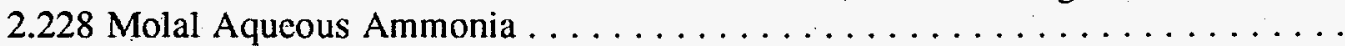

B.6 Ammonia Partial Pressures for Simulant SY1-SIM-93B Containing 3.532 Molal Aqueous Ammonia . . . . . . . . . . . . . . . . . .

B.7 Ammonia Partial Pressures for Simulant SY1-SIM-91A Containing 1.274 Molal Aqueous Ammonia . . . . . . . . . . . . . . . . . . . .

B.8 Ammonia Partial Pressures for Simulant SY1-SIM-91A Containing 2.297 Molal Aqueous Ammonia .

B.9 Ammonia Partial Pressures for Simulant SY1-SIM-91A Containing 3.305 Molal Aqueous Ammonia .

B.10 Estimated Aqueous Ammonia Concentrations in Tank 241-SY-101 Wastes as a Function of Temperature and Water Content, Based on Henry's Law Constants Determined for Simulant SY1-SIM-91A . . . . . . . . . . . . . . . . .

C.1 Surface Tension of Sodium Hydroxide Solutions $\ldots \ldots \ldots \ldots \ldots \ldots \ldots \ldots$

C.2 Surface Tension of Sodium Nitrate Solutions 


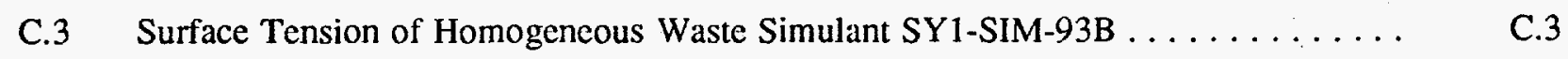

C.4 Surface Tension of Heterogeneous Waste Simulant SY1-SIM-91A $\ldots \ldots \ldots \ldots$ C.3

C.5 Surface Tension of Heterogencous Waste Simulant SY1-SIM-93B with 1.5 Weight

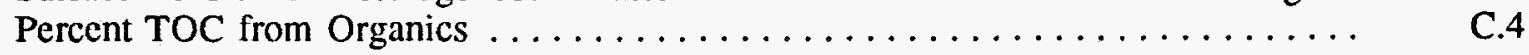

C.6 Surface Tension of Heterogeneous Waste Simulant SY1-SIM-93B Using Different Bubble Gases . . . . . . . . . . . . . . . . . . . . . . . 


\subsection{Introduction}

Radioactive and chemical wastes left from defense materials production activities are temporarily stored in large underground tanks at the Hanford Site in south central Washington State (Tank Waste Science Panel 1991). Some of these wastes are in the form of a thick slurry ("doubleshell slurry") containing sodium nitrate, sodium nitrite, sodium aluminate, sodium hydroxide, sodium carbonate, organic complexants and buffering agents, complexant fragments and other minor components (Herting et al. 1992a; Herting et al. 1992b; Campbell et al. 1994).

As a result of thermal and radiolytic processes, a number of gases are known to be produced by some of these stored wastes, including ammonia, nitrous oxide, nitrogen, hydrogen, and methane (Babad et al. 1991; Ashby et al. 1992; Mcisel et al. 1993; Ashby et al. 1993; Ashby et al. 1994; Bryan et al. 1993; U.S. Department of Energy 1994). Before the emplacement of a mixer pump, these gases were retained in and periodically released from Tank 241-SY-101, a double-shell tank at the Hanford Site (Babad et al. 1992; U.S. Department of Energy 1994). Gases are believed to be retained primarily in the form of bubbles attached to solid particles (Bryan, Pederson, and Scheele 1992), with very little actually dissolved in the liquid. Ammonia is an exception. The relation between the concentration of aqueous ammonia in such concentrated, caustic mixtures and the ammonia partial pressure is not well known, however.

Dissolved electrolytes and many non-elcctrolytes are well known to lower the solubility of a gas in that fluid when compared to pure water (Setschenow 1889). The effect of salt concentration on the solubility of a sparingly soluble gas is often described as follows:

$$
\log \left(\mathrm{c}_{\mathrm{G}, \mathrm{d}} / \mathrm{c}_{\mathrm{G}}\right)=\mathrm{K} \mathrm{c}_{\mathrm{s}}
$$

where $c_{G, 0}$ is the solubility of a gas in pure water, $c_{G}$ is the solubility of that same gas in the presence of a dissolved salt, $\mathrm{c}_{\mathrm{s}}$ is the concentration of a dissolved salt, and $\mathrm{K}$ is the Setschenow constant. The Setschenow constant is specific to a particular gas and is additionally temperature-dependent. The above expression has been used successfully to describe solubility trends in electrolyte solutions for electrolyte concentrations up to approximately 0.1 molal. At high electrolyte concentrations, however, the salting-out effect (lowering of the solubility) following Equation (1) tends to be overestimated (Schumpe 1993).

In strongly basic solutions, the solubility of ammonia in an aqueous solution may be represented as follows:

$$
\mathrm{NH}_{3}(\mathrm{~g})=\mathrm{NH}_{3}(\mathrm{aq})
$$

Ionization of aqueous ammonia to form the ammonium ion may be ignored. The Henry's Law constant $\mathrm{K}_{\mathrm{H}}$ (mol/ $\left.\mathrm{kg}-\mathrm{atm}\right)$ is defined by the expression:

$$
\mathrm{K}_{\mathrm{H}}=\gamma\left(\mathrm{NH}_{3}\right) \mathrm{m}\left(\mathrm{NH}_{3}\right) / \mathrm{p}\left(\mathrm{NH}_{3}\right)
$$

where $\gamma\left(\mathrm{NH}_{3}\right)$ is the activity coefficient for ammonia, $\mathrm{m}\left(\mathrm{NH}_{3}\right)$ denotes molality, and $\mathrm{p}\left(\mathrm{NH}_{3}\right)$ is the ammonia partial pressure (atm). To calculatc ammonia partial pressures for a given aqueous ammonia concentration, values of the activity coefficient for ammonia specific to that solution as well as the Henry's law constant are needed. For ammonia in pure water, Henry's Law constants have been given by Clegg and Brimblecombe (1989): 


$$
\text { In }\left(K_{1 \mathrm{H}}\right)=-8.09694+3917.50 / \mathrm{T}-0.00314 \mathrm{~T}
$$

where $\mathrm{T}$ is temperature (K). A similar expression has been given by Edwards et al. (1978). The term $\gamma\left(\mathrm{NH}_{3}\right)$ is less easily obtained for concentrated solutions of multicomponent electrolytes. Clegg and Brimblecombe (1989) have used the ion-interaction parameter model of Pitzer $(1979 ; 1987)$ to calculate $\gamma\left(\mathrm{NH}_{3}\right)$ in pure aqueous and multicomponent solutions. Despite successes in modelling multicomponent electrolyte solutions, an expcrimental determination of ammonia solubility in simulated waste mixtures remains of value. The simulants are generally more concentrated than solutions from which ion interaction parameters were originally derived. Also, ion interaction parameters are not known for all of the components of the waste.

Among the parameters needed for modelling retention and release in Hanford wastes is surface tension (Allemann et al. 1993). Surface tension is one of the key parameters that determines the morphology of gas bubbles in a slurry. Detachment of gas bubbles from solid particles by acoustic waves, one of the mitigation strategies being considered in addition to the use of a mixer pump to prevent gas retention and release cycles, also depends on the surface tension (Cannon 1994). Surface tension values for aqueous solutions generally increase with increased electrolyte concentrations, such as sodium nitrate, sodium nitrite, sodium carbonate, and sodium hydroxide, and are lowered by increases in temperature and by the addition of aqueous ammonia and certain organics (CRC Handbook of Chemistry and Physics, 71st Edition, 1990). Because of difficulties in predicting surface tension values in complex waste mixtures, it is also useful to experimentally detcrmine this parameter. 


\subsection{Experimental Methods}

\subsection{Waste Simulant Compositions}

In addition to sodium hydroxide solutions, two simulant compositions were used in this study: a homogeneous simulant designated SY1-SIM-93B, and a heterogeneous (slurry) simulant designated SY1-SIM-91A. Both simulants contain the principal inorganic chemicals known to be present in the actual wastes (Herting et al. 1992a; Herting et al. 1992b; Bryan and Pederson 1994). The compositions of these simulants are given in Table 1 and Table 2, renormalized from compositions given by. Bryan and Pederson (1994) to reflect the absence of organics. Aluminum is shown in Table 1 as $\mathrm{NaAlO}_{2}$ rather than as $\mathrm{NaAl}(\mathrm{OH})_{4}$, as was given previously by Bryan and Pederson (1994). This representation is more appropriate because sodium aluminate is the predominant form in strongly caustic solutions (Pourbaix 1974; Barney 1976). In Table 2, the simulant composition also has been recalculated in the form of Table 1 .

Table 1. Concentrations of Components Used in Slurry Simulant SY1-SIM-91A

\begin{tabular}{|c|c|c|}
\hline Component & $\underline{\mathrm{M}(\mathrm{mol} / \mathrm{L})}$ & Weight \\
\hline $\mathrm{NaOH}$ & 2.3 & 6.4 \\
\hline $\mathrm{NaAlO}_{2}$ & 2.2 & 12.2 \\
\hline $\mathrm{NaNO}_{3}$ & 3.7 & 22.0 \\
\hline $\mathrm{NaNO}_{2}$ & 3.2 & 15.4 \\
\hline $\mathrm{Na}_{2} \mathrm{CO}_{3}$ & 0.6 & 4.4 \\
\hline $\mathrm{H}_{2} \mathrm{O}$ & & 39.6 \\
\hline Total & & 100.0 \\
\hline
\end{tabular}

Table 2. Concentrations of Components Used in Slurry Simulant SY1-SIM-93B

\begin{tabular}{|c|c|c|c|c|}
\hline Component & $\mathrm{M}(\mathrm{mol} / \mathrm{L})$ & Wcight \% & Expected in Simulant & Weight \% \\
\hline $\mathrm{NaOH}$ & 3.4 & 11.21 & $\mathrm{NaOH}$ & 5.53 \\
\hline $\mathrm{Al}\left(\mathrm{NO}_{3}\right)_{3} \cdot 9 \mathrm{H}_{2} \mathrm{O}$ & 0.43 & 13.29 & $\mathrm{NaAlO}_{2}$ & 2.90 \\
\hline $\mathrm{NaNO}_{3}$ & 0.4 & 2.80 & $\mathrm{NaNO}_{3}$ & 11.83 \\
\hline $\mathrm{NaNO}_{2}$ & 2.0 & 11.38 & $\mathrm{NaNO}_{2}$ & 11.38 \\
\hline $\mathrm{Na}_{2} \mathrm{CO}_{3}$ & 0.2 & 1.75 & $\mathrm{Na}_{2} \mathrm{CO}_{3}$ & 1.75 \\
\hline $\mathrm{H}_{2} \mathrm{O}$ & & 59.58 & $\mathrm{H}_{2} \mathrm{O}$ & 66.60 \\
\hline Total & & 100.01 & & 99.99 \\
\hline
\end{tabular}




\subsection{Solubility Measurements}

Ammonia partial pressures were determined as a function of temperature, solution composition, and ammonia content using a modified isoteniscope. The apparatus is shown schematically in Figure 1. The temperature of the apparatus was maintained within $\pm 0.1^{\circ} \mathrm{C}$ in a temperature-controlled, well-stirred water bath. Pressures were measured using a mercury-filled manometer, which could be read to $\pm 0.3 \mathrm{~mm} \mathrm{Hg}$. Test solutions, approximately $25 \mathrm{grams}$, were introduced into the sample vessel and degassed by evacuation. Following determination of the water vapor pressure for the test solution as a function of temperature, an appropriate quantity of aqueous ammonia was introduced into the test vessel by injection through a scptum using a syringe. The quantity of ammonia introduced was determined by weight. Care was taken so as not to introduce air into the sample vessel when aqueous ammonia was being added.

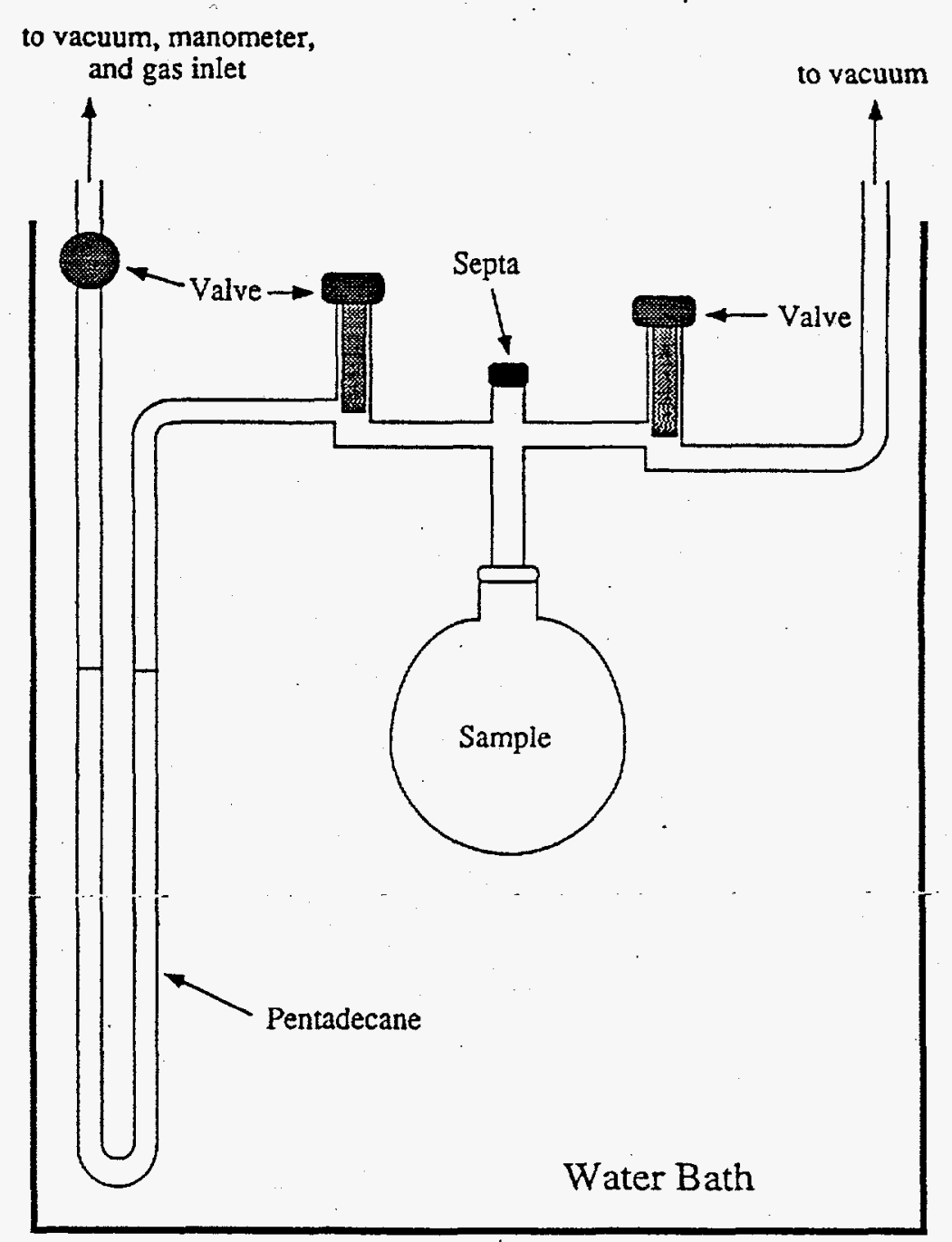

Figure 1. Schematic of the Isoteniscope Used to Evaluate Ammonia Solubilitics in Electrolyte Solutions 
A pentadecane-filled U-tube separated the sample vessel from the mercury manometer. Pentadecane provides a low vapor pressure, negligible reactivity towards ammonia, and negligible ability to dissolve ammonia. Sufficient nitrogen was introduced on the mercury manometer side to equalize the liquid levels of the U-tube. Mercury manometer readings thus reflected the total vapor pressure within the test vessel.

Included in ammonia equilibria studies were sodium hydroxide solutions ranging in concentration from 0.5 to 7.0 molal and the waste simulants SY1-SIM-91A and SY1-SIM-93B. Organic components were excluded from the waste simulant compositions. Ammonia is known to be produced via the degradation of complexants and other organic compounds in simulated waste mixtures (Ashby et al. 1994; Meisel et al. 1993; Bryan and Pederson 1994), which could have complicated the interpretation of results if organic components were included.

\subsection{Surface Tension Measurements}

The maximum bubble pressure method (Sugden 1922) was chosen to evaluate the surface tension of waste simulants. A schematic of this apparatus is given in Figure 2. In this method, two stainless steel capillary tubes of different diameters were inserted into a simulant solution at equal depths. The inner diameter of one capillary tube was approximately $2 \mathrm{~mm}$ in diameter, while the second capillary was approximately $0.1 \mathrm{~mm}$ in diameter. Nitrogen gas was made to flow through each capillary tube at a rate and pressure sufficient to produce a bubble every 5 to 30 seconds. The maximum pressure required to produce a bubble was recorded using a strip chart recorder as a function of temperature and solution composition.

Surface tension is determined from the following expression:

$$
\gamma=\mathrm{A}\left(\mathrm{P}_{1}-\mathrm{P}_{2}\right)\left(1+0.69 \mathrm{R}_{2} \mathrm{gD} /\left(\mathrm{P}_{1}-\mathrm{P}_{2}\right)\right)
$$

where $\mathrm{A}$ is an apparatus constant that is determined using a standard of known surface tension, $\mathrm{P}_{1}$ and $P_{2}$ are maximum bubble pressures for the small and large diameter capillary tubes, respectively; $R_{2}$ is the radius of the large diameter tube, $g$ is the gravitational constant, and $D$ is the liquid density. Unlike a number of other surface tension measurement techniques, the maximum bubble pressure method is independent of contact angle for finite contact angles less than $90^{\circ}$. This is an important advantage, considering that solid alumina surfaces immersed in a simulated waste mixture exhibited partial hydrophobic character that depended on the concentration of complexants in the liquid (Bryan, Pederson, and Scheele 1992).

Surface tension measurements were performed for the homogeneous simulant SY1-SIM-93B with no organic components present, with sodium citrate, glycine, sodium formate, tetrasodium EDTA, and tri-sodium hydroxyethylethylenediaminetriacetic acid (HEDTA) present to give a total organic carbon concentration of 1.5 weight percent. Surface tension measurements were also obtained for both simulant compositions containing 0,1 , and 2 weight percent aqueous ammonia. Nitrogen gas was used primarily in these maximum bubble pressure measurements. Limited measurements were also performed using oxygen, methane, nitrous oxide, and hydrogen. 


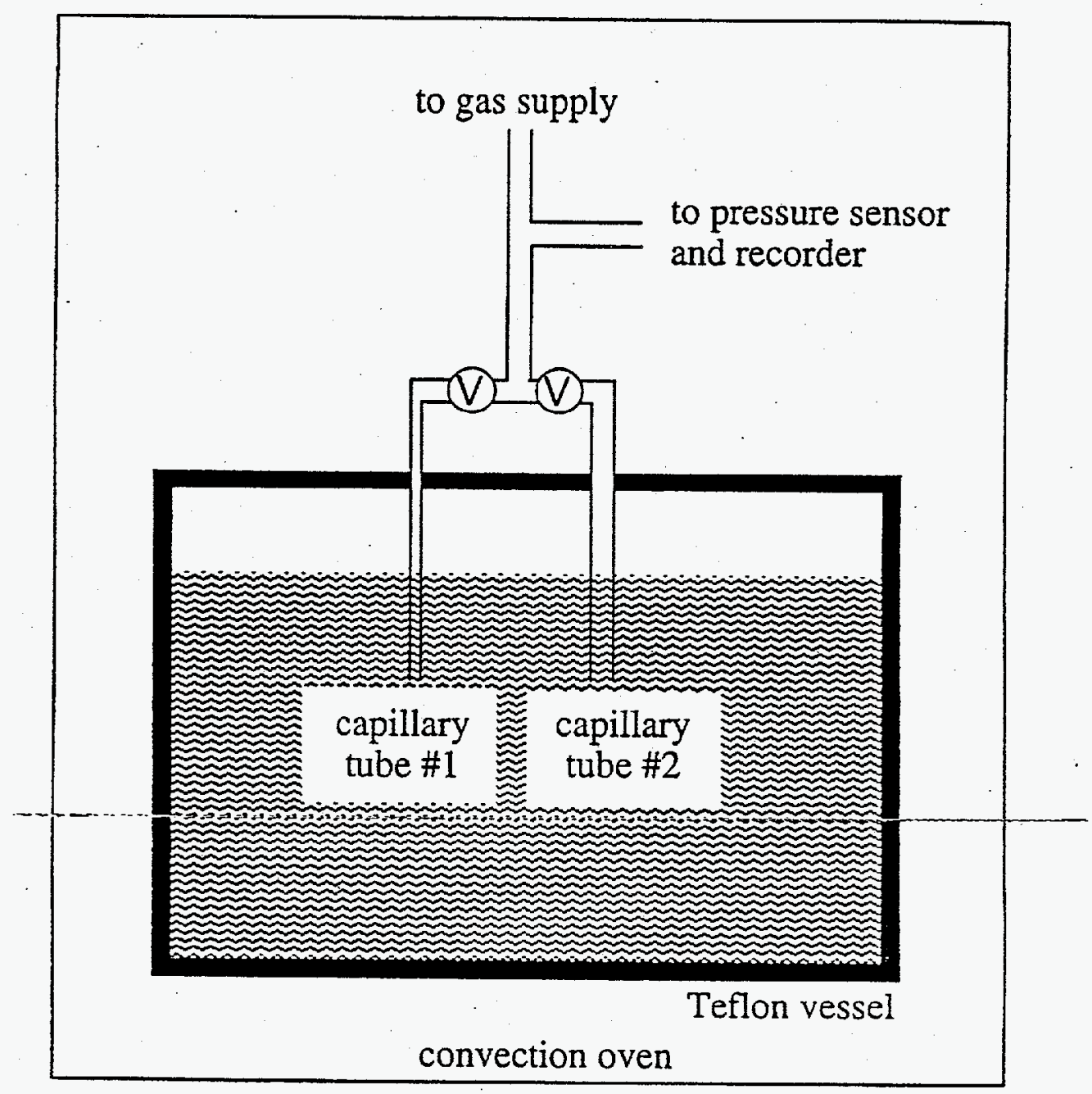

Figure 2. Schematic of the Maximum Bubble Pressure Apparatus Used to Measure the Surface Tension of Simulant Mixtures. The maximum bubble pressure method was originally developed by Sugden (1922). 


\subsection{Ammonia Solubility Determinations in Sodium Hydroxide Solutions and in Waste Simulant Mixtures}

Ammonia equilibrium partial pressures were determined as a function of temperature (25 to $\left.70^{\circ} \mathrm{C}\right)$ for sodium hydroxide solutions $(0.5$ to 7.0 molal) and waste simulant mixtures, to which known quantities of aqueous ammonia had been added. Ammonia partial pressures were derived by subtracting the water partial pressure from the total pressure for each solution. Henry's Law constants were calculated from these data. Results were compared to predicted values obtained using the Pitzer ion interaction model. From ammonia equilibria data obtained for waste simulants and from the composition of gases found in Tank 241-SY-101 immediately following a gas release event, the concentration of aqueous ammonia in the wastes was estimated.

\subsection{Water Partial Pressure Measurements}

Water partial pressures were determined for the waste simulant compositions SY1-SIM-93B and SY1-SIM-91A as well as for sodium hydroxide solutions as a function of temperature in the range $25^{\circ} \mathrm{C}$ to $70^{\circ} \mathrm{C}$. The data were fitted to an equation of the widely-used form $\ln (\mathrm{p})=\mathrm{A} / \mathrm{T}+\mathrm{B}$. This enabled the water vapor contribution to the total pressure of solutions containing aqueous ammonia to be subtracted for any specific experimental temperature. Fitted parameters are given in Table 3. Water partial pressures for sodium hydroxide solutions are shown in Figure 3, and are additionally given in Appendix A, Tables A.1 through A.6. Water partial pressure data for simulants SY1-SIM93B and SY1-SIM-91A are shown in Figure 4 and are also given in Appendix B, Tables B.1 and B.2, respectively. Water partial pressures for sodium hydroxide solutions are in good agreement with those given by Perry and Green (Perry's Chemical Engineering Handbook, 6th Ed. 1984), decreasing with increased sodium hydroxide concentration. Water vapor pressures for the more concentrated simulant, SY1-SIM-91A, were smaller than those determined for the homogeneous simulant, SY1SIM-93B, for a given temperature. This behavior is the result of the well-known lowering of the activity of water by the presence of dissolved electrolytes.

Table 3. Fitted Parameters for Water Partial Pressures as a Function of Temperature for the Range 25 to $70^{\circ} \mathrm{C}, \ln (\mathrm{p})=\mathrm{A} / \mathrm{T}(\mathrm{K})+\mathrm{B}$

\begin{tabular}{ccc} 
Solution & \multicolumn{1}{c}{$\mathrm{A}$} & $\mathrm{B}$ \\
\cline { 1 - 1 } $0.50 \mathrm{~m} \mathrm{NaOH}$ & -5085.0 & 13.596 \\
$1.00 \mathrm{~m} \mathrm{NaOH}$ & -5042.2 & 13.433 \\
$2.50 \mathrm{~m} \mathrm{NaOH}$ & -5106.4 & 13.563 \\
$3.99 \mathrm{~m} \mathrm{NaOH}$ & -5200.5 & 13.769 \\
$5.47 \mathrm{~m} \mathrm{NaOH}$ & -5110.8 & 13.377 \\
$6.95 \mathrm{~m} \mathrm{NaOH}$ & -5094.8 & 13.237 \\
SY1-SIM-93B & -5114.3 & 13.377 \\
SY1-SIM-91A & -5356.0 & 13.507
\end{tabular}




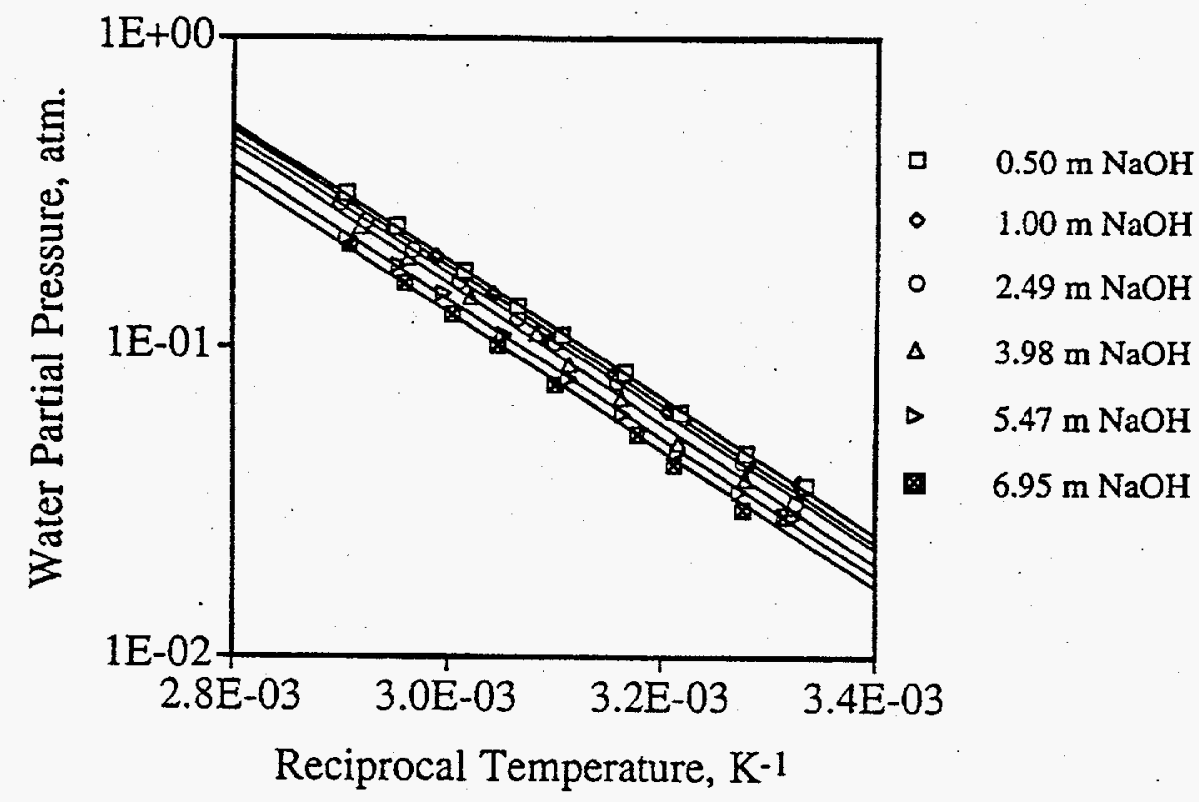

Figure 3. Partial Pressure of Water Versus Temperature for Sodium Hydroxide Solutions, Corresponding to Data Given in Appendix A, Tables A.1 through A.6. The solid lines are least squares fits to the data. Fitted parameters are given in Table 3.

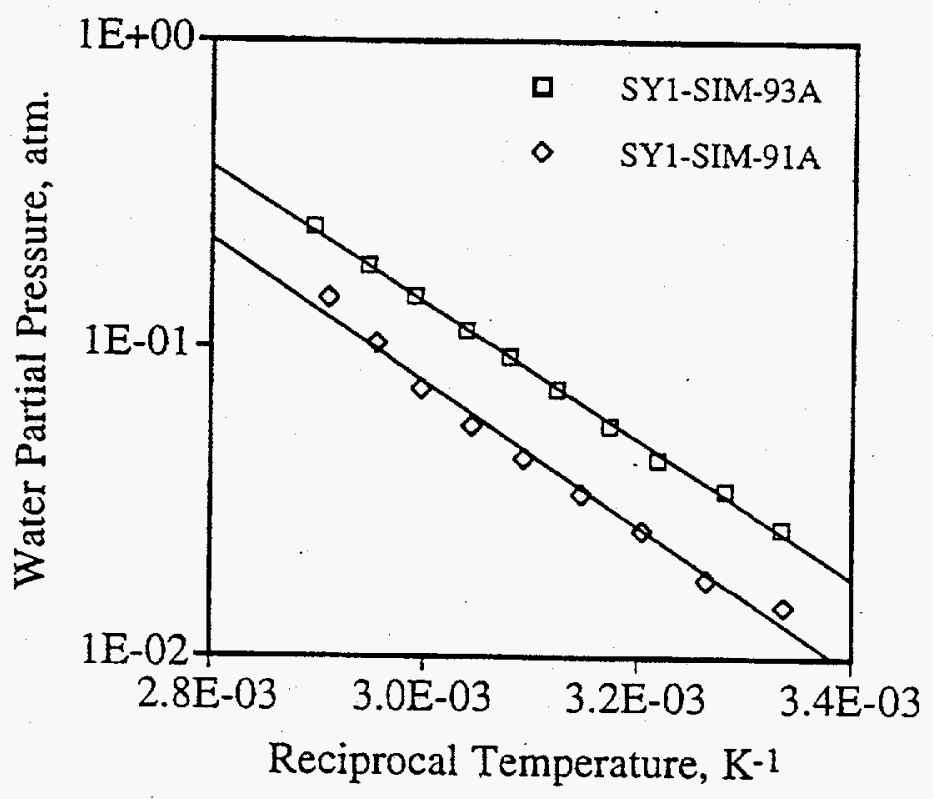

Figure 4. Partial Pressure of Water Versus Tempcrature for the Waste Simulants SY1-SIM-93B and SY1-SIM-91A, Corresponding to the Data Given in Appendix B, Tables B.1 and B.2. Fitted parameters are listed in Table 3. 


\subsection{Ammonia Partial Pressure and Henry's Law Constants}

Ammonia partial pressures for each solution, temperature, and aqueous ammonia concentration were calculated from total pressure data and the equations for water partial pressures given in Table 3. Total pressure, ammonia partial pressure and water partial pressure data for sodium hydroxide solutions are listed in Appendix A, Tables A.7 through A.12. Similar data for the simulant SY1-SIM-93B are provided in Appendix B, Tables B.3 through B.6, corresponding to four levels of aqueous ammonia addition. Data for the simulant SY1-SIM-91A are provided in Appendix B, Tables B.7 through B.9, corresponding to three levels of aqueous ammonia addition.

For an approximatcly constant concentration of aqueous ammonia, the partial pressure of ammonia increased with increases in temperature and with increases in the concentration of dissolved electrolytes. For sodium hydroxide solutions, ammonia partial pressures are plotted as a function of temperature in Figure 5. Similar bchavior was followed by the simulants SY1-SIM-93B and SY1SIM-91A, as shown in Figure 6 and Figure 7, respectively. Ammonia partial pressures obtained for the more concentrated simulant (-91A) were substantially higher than for the homogeneous simulant $(-93 \mathrm{~B})$, for the same temperature and aqucous ammonia concentration. For the $-91 \mathrm{~A}$ simulant, a 3 weight percent aqueous ammonia concentration is expected to yicld an ammonia partial pressure of approximately $1 \mathrm{~atm}$. at $50^{\circ} \mathrm{C}$, the approximate temperature of the wastes stored in Tank $241-\mathrm{SY}-101$.

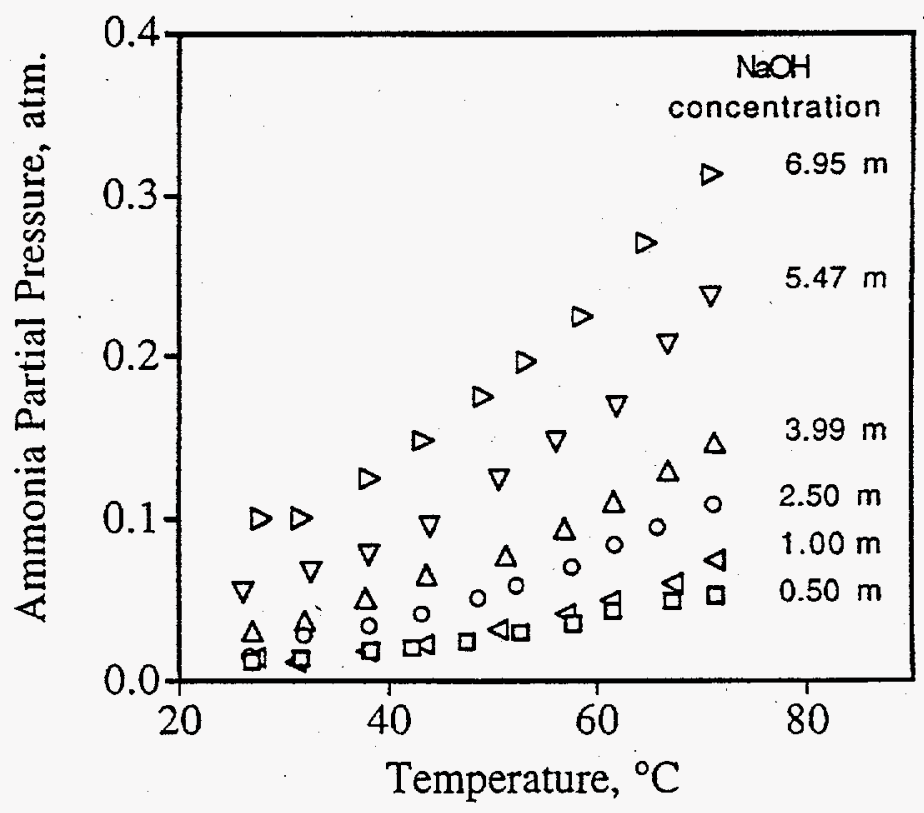

Figure 5. Ammonia Partial Pressure Versus Temperature for Sodium Hydroxide Solutions. The solutions each contained approximatcly 0.6 weight percent aqueous ammonia. 


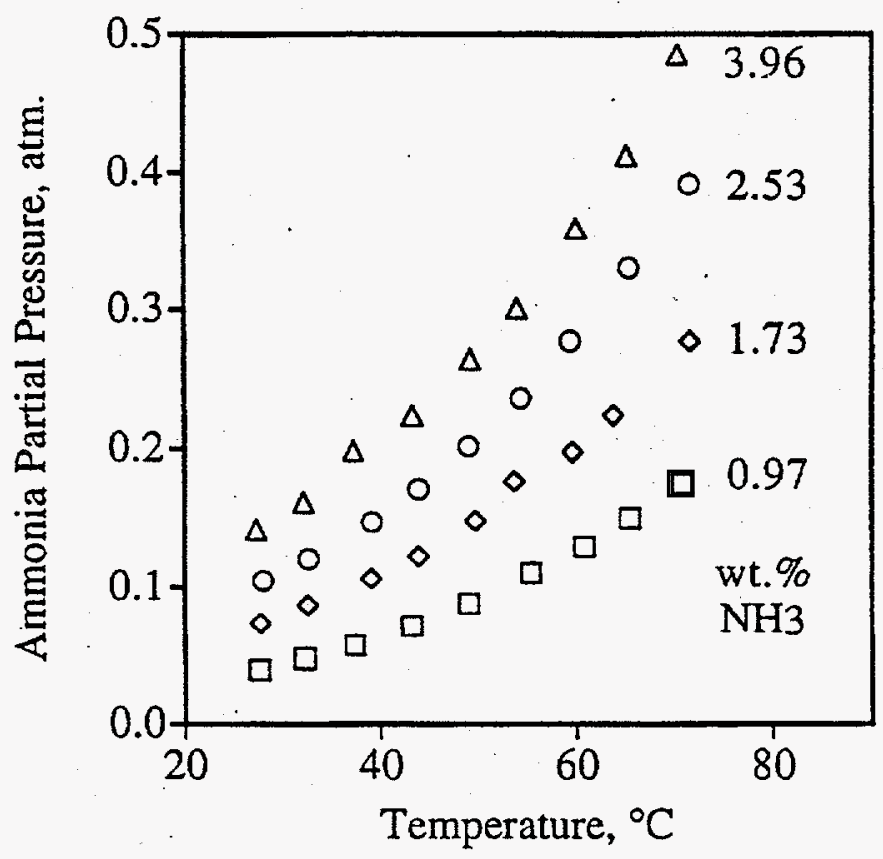

Figure 6. Ammonia Partial Pressure Versus Temperature for the Simulant SY1-SIM-93B for Several Aqueous Ammonia Concentrations

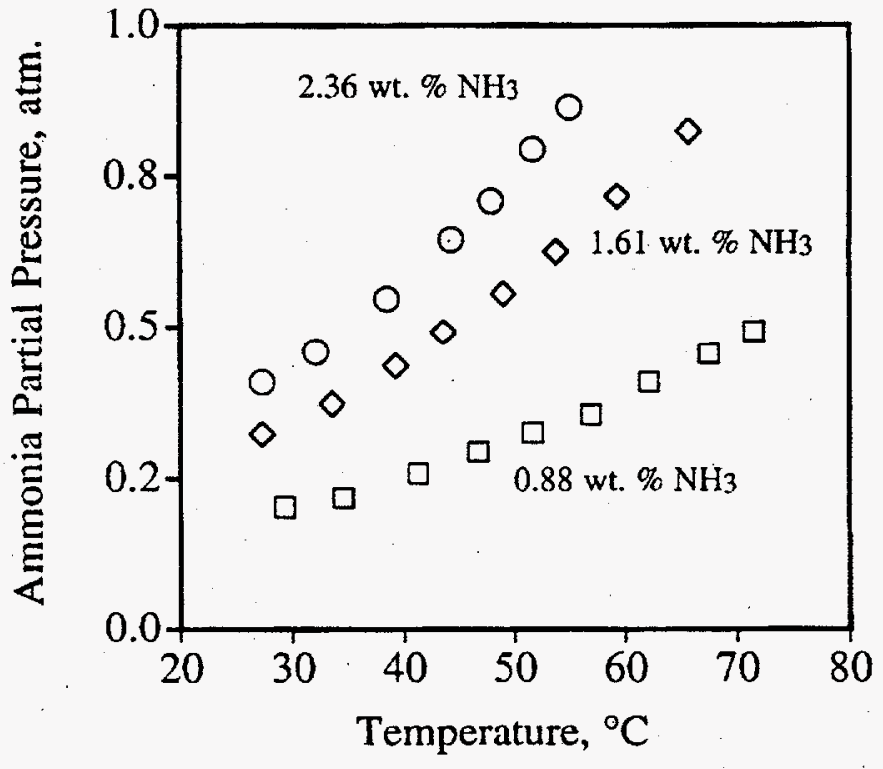

Figure 7. Ammonia Partial Pressure Versus Temperature for the Simulant SY1-SIM-91A 
By substituting ammonia partial pressures and aqueous ammonia concentrations into Equation (3), Henry's Law constants were calculated for each temperature and solution concentration. Since activities of aqueous ammonia are not known explicitly for various solutions and temperatures, calculated values actually reflect $\mathrm{K}_{\mathrm{H}} / \gamma\left(\mathrm{NH}_{3}\right)$. Calculated Henry's Law constants for sodium hydroxide solutions are included in Appendix A, Tables A.7 through A.12. For the waste simulants, similar results are included in Appendix B, Tables B.3 through B.9.

For sodium hydroxide solutions, calculated Henry's Law constants values clearly decreased with increased quantity of dissolved electrolyte at a constant temperature, corresponding to a raising of $\gamma\left(\mathrm{NH}_{3}\right)$ by dissolved electrolytes. For a fixed aqueous ammonia concentration and electrolyte concentration, Henry's Law constants decreased with increased temperature. Calculated Henry's Law constants for various sodium hydroxide solutions are summarized as a function of temperature in Figure 8. Also included in Figure 8 for comparison are results for water calculated from Equation (4), from Clegg and Brimblecombe (1989). Equation (4) was derived for water/ammonia systems in the temperature range 0 to $40^{\circ} \mathrm{C}$, so the calculated water/ammonia results included in Figure 8 in the temperature range 40 to $70^{\circ} \mathrm{C}$ represent an extrapolation.

Henry's Law constants determined for the waste simulants SY1-SIM-91A and SY1-SIM-93B also decreased with increased temperature. Smallest Henry's Law constants were obtained for the slurry simulant SY1-SIM-91A, which also contains the higher quantity of dissolved electrolytes. Results for the two simulants are shown in Figure 9 as a function of temperature. Again, Henry's Law constants for water are included for comparison. In Figure 10, Henry's Law constants for ammonia/ water (from Equation (4)) divided by experimentally determined values for the two simulants are given versus temperature. This is approximately equal to the ratio of the activity coefficient of ammonia in the simulant divided by that in water. The ratio decreased for both simulants with increased temperature, with the largest change seen for the more concentrated simulant.

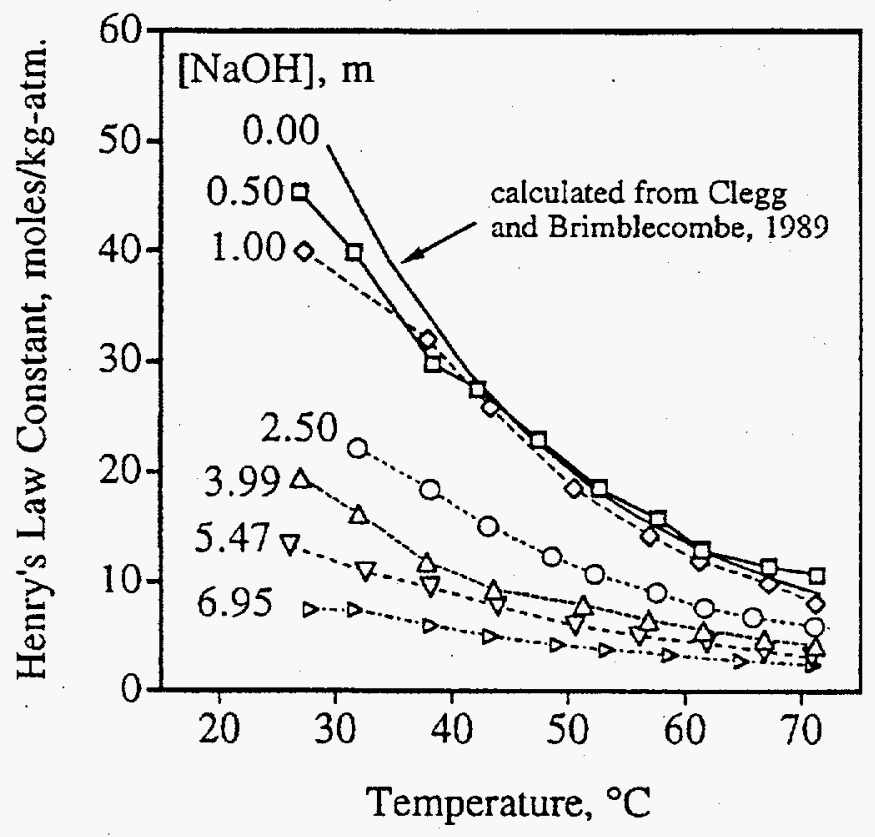

Figure 8. Henry's Law Constants as a Function of Temperature for Sodium Hydroxide Solutions. Results for water were calculated from the expression given by Clegg and Brimblecombe (1989). 


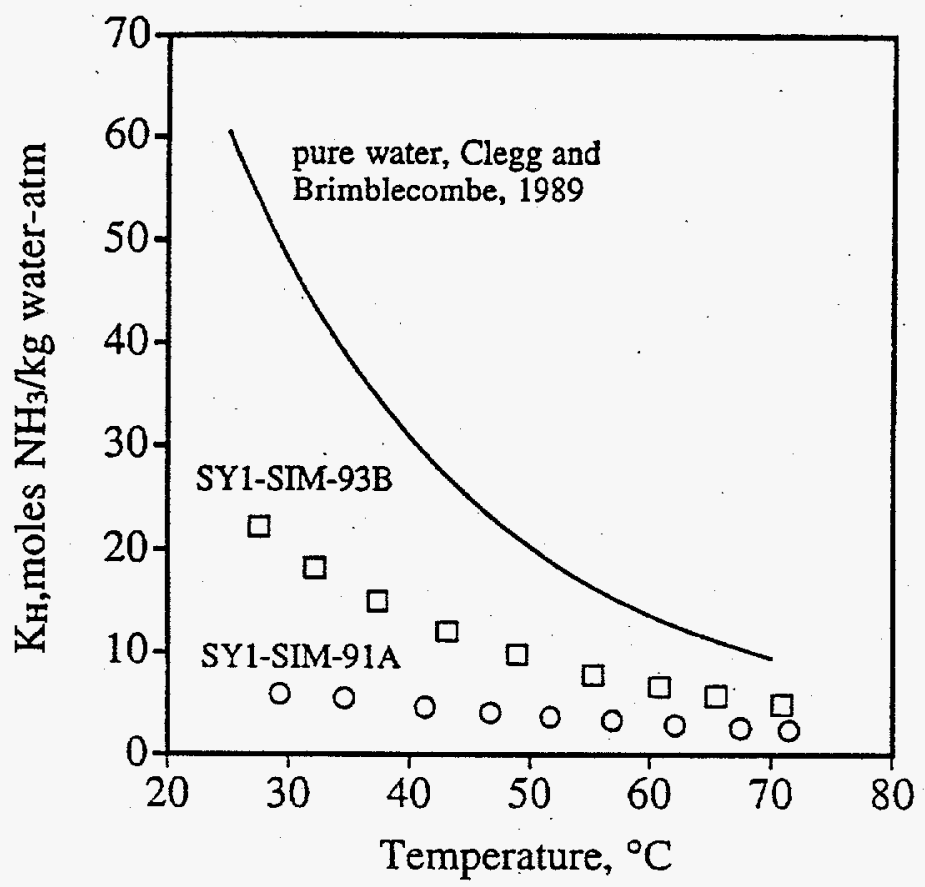

Figure 9. Henry's Law Constants as a Function of Temperature for the Waste Simulants SY1-SIM-93B and SY1-SIM-91A. Values for the simulants corresponds to an aqueous ammonia concentration of approximately 0.6 weight percent, the smallest concentration used in these studies.

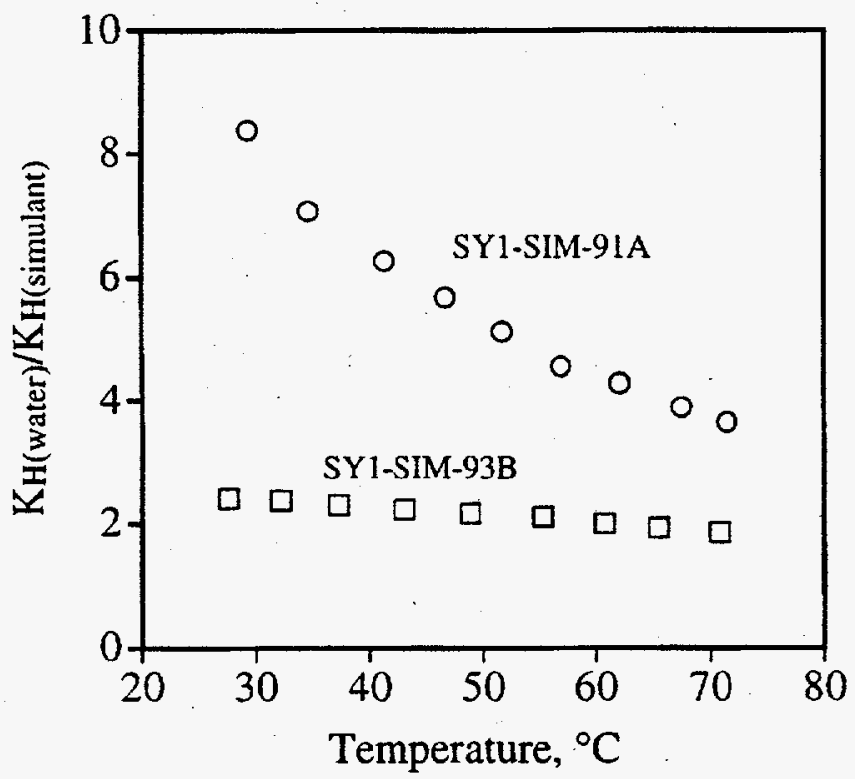

Figure 10. Ratio of the Activity of Ammonia in Simulant Mixtures to that of Ammonia in Water as a Function of Temperature 
Higher additions of aqueous ammonia to the simulant mixtures resulted in an upwards trend in the magnitude of the Henry's Law constants. Results for simulants SY1-SIM-93B and SY1-SIM-91A are given in Figure 11 and Figure 12, respectively. When aqueous ammonia was added to the simulant mixture in the present study, the quantity of water in the sample also increased. The result was a more dilute solution, higher water activities, and reduced ammonia partial pressures. This behavior was somewhat less pronounced for the slurry simulant, SY1-SIM-91A, presumably because the effect of water addition was offset by the dissolution of additional salts.

Henry's Law constants for sodium hydroxide solutions and for the two simulant compositions were fitted to an equation of the form: $\ln K_{H}=A+B / T(K)+C T(K)$, where $A, B$, and $C$ are fitted constants. This form is identical to that of Equation (3). Fitted parameters for sodium hydroxide solutions and for the waste simulants are given below in Table 4.

\subsection{Comparison to Ion Interaction Model}

Activity coefficients for ammonia in clectrolyte solutions may be calculated from the ion interaction model developed by Pitzer (1973a; 1973b; 1979; 1987). Originally developed for strong electrolytes, this model was shown to be extendable to neutral solutes (Harvie, Moller, and Weare 1984). Clegg and Brimblecombe (1989) have reviewed available literature and compiled ion interaction parameters for ammonia in simple and multicomponent electrolyte solutions.

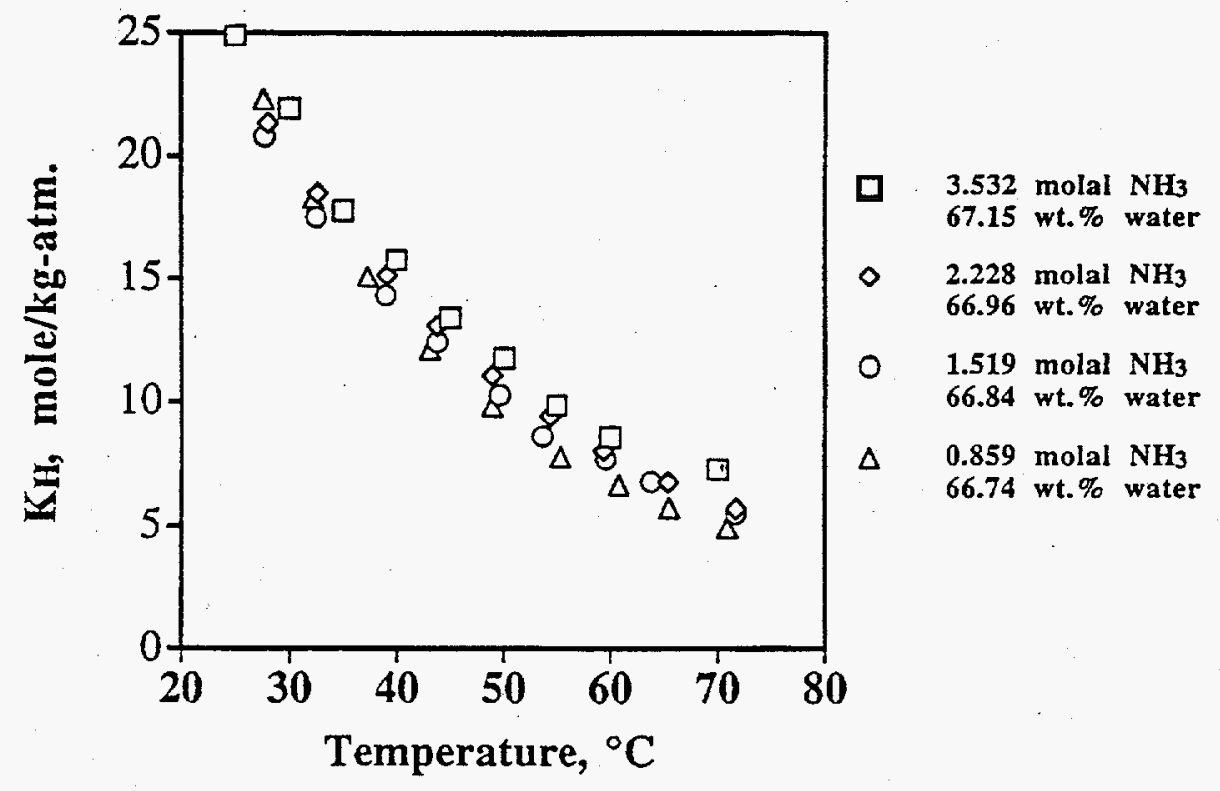

Figure 11. Henry's Law Constants for the Simulant SY1-SIM-93B Versus Temperature, Corresponding to Several Aqueous Ammonia Concentrations 


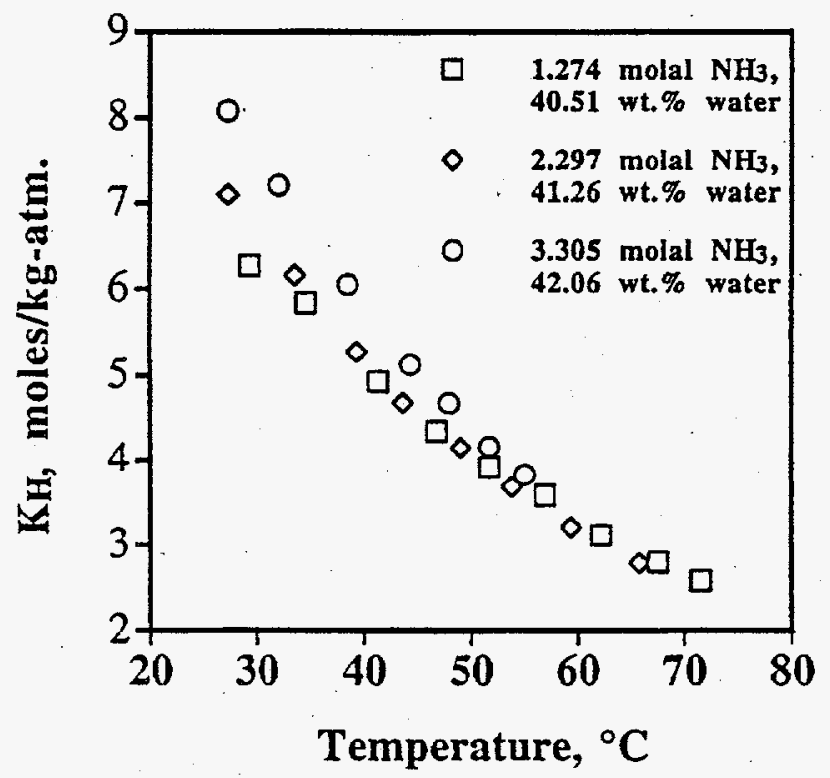

Figure 12. Henry's Law Constants for the Simulant SY1-SIM-91A Versus Temperature, Corresponding to Scveral Aqueous Ammonia Concentrations

Table 4. Fitted Constants for Henry's Law Constants for Ammonia in Sodium Hydroxide Solutions and in Waste Simulants SY1-SIM-91A and SY1-SIM-93B; $\ln K_{\mathrm{H}}=\mathrm{A}+\mathrm{B} / \mathrm{T}(\mathrm{K})+\mathrm{CT}(\mathrm{K})$; Temperature Range 25 to $70^{\circ} \mathrm{C}$; Calculated from Tables A.7 through A.12, B.3, and B.7.

\begin{tabular}{ccccc} 
Solution & \multicolumn{1}{c}{$\mathrm{A}$} & & $\mathrm{B}$ & $\mathrm{C}$ \\
& & & & \\
$0.50 \mathrm{~m} \mathrm{NaOH}$ & -7.062 & & 3395.2 & -0.001350 \\
$1.00 \mathrm{~m} \mathrm{NaOH}$ & -7.107 & & 3524.2 & -0.002768 \\
$2.50 \mathrm{~m} \mathrm{NaOH}$ & -7.287 & 3361.1 & -0.002441 \\
$3.99 \mathrm{~m} \mathrm{NaOH}$ & -7.418 & 3284.7 & -0.002015 \\
$5.47 \mathrm{~m} \mathrm{NaOH}$ & -7.486 & 3174.1 & -0.001629 \\
$6.95 \mathrm{~m} \mathrm{NaOH}$ & -7.629 & & 3010.3 & -0.000794 \\
SY1-SIM-93B & -7.357 & & 3330.1 & -0.002139 \\
SY1-SIM-91A & -7.577 & 2571.3 & +0.003076
\end{tabular}


The activity coefficient for ammonia in a solution of a salt $\mathrm{M}_{\mathrm{v}_{+}} \mathrm{X}_{\mathrm{v}_{-}}$is given by (Clegg and Brimblecombe 1989):

$$
\begin{gathered}
\ln \left(\gamma\left(\mathrm{NH}_{3}\right)\right)=2 \mathrm{~m}\left(\mathrm{NH}_{3}\right) \lambda_{\mathrm{N}, \mathrm{N}}+2 \mathrm{~m}\left(\mathrm{M}_{\mathrm{v}+} \mathrm{X}_{\mathrm{v}-}\right)\left(v^{+} \lambda_{\mathrm{N}, \mathrm{M}}+v^{-} \lambda_{\mathrm{N}, \mathrm{X}}\right)+ \\
6 m\left(\mathrm{M}_{v^{+}} \mathrm{X}_{\mathrm{v}_{-}}\right) \mathrm{m}\left(\mathrm{NH}_{3}\right)\left(v^{+} \mu_{\mathrm{N}, \mathrm{N}, \mathrm{M}}+v^{-} \mu_{\mathrm{N}, \mathrm{N}, \mathrm{X}}\right)
\end{gathered}
$$

where $\lambda_{\mathrm{N}, \mathrm{N}}$ is an ammonia self-interaction parameter, $\lambda_{\mathrm{N}, \mathrm{M}}$ and $\lambda_{\mathrm{N}, \mathrm{X}}$ are ammonia-cation and ammonia-anion interaction parameters, respectively, and $\mu_{\mathrm{N}, \mathrm{N}, \mathrm{M}}$ and $\mu_{\mathrm{N}, \mathrm{N}, \mathrm{X}}$ are second-order ammonia-cation and ammonia-anion interaction parameters, respectively. Higher order interaction terms from the original reference have been dropped in Equation (6). In its simplest form, Equation (6) corresponds to that of Equation (1), the Setschenow Equation (Setschenow 1889). The term $\lambda_{\mathrm{N}, \mathrm{N}}$ is further defined by the expression (Clegg and Brimblecombe 1989):

$$
\lambda_{\mathrm{N}, \mathrm{N}}=0.033161-21.12816 / \mathrm{T}(\mathrm{K})+4665.1461 / \mathrm{T}^{2}
$$

Clegg and Brimblecombe (1989) have compiled values for these first and second order interaction coefficients for a number of salts, based on a survey of available literature. They have concluded that the interaction parameters are generally additive for multicomponent clectrolytes. From Equations (6) and (7) and using a value for $K_{11}$ for ammonia/water of $60.72 \mathrm{~atm} / \mathrm{kg}$-mole, it is possible to predict Henry's Law constants for electrolyte solutions.

Reasonably good agreement was obtained between Henry's Law constants determined in this study and results calculated using the ion interaction model for sodium hydroxide solutions, as is shown in Figure 13. Present results were corrected to $25^{\circ} \mathrm{C}$ using the parameters of Table 4 . The solid line in Figure 13 was obtained using the ion interaction parameters recommended by Clegg and Brimblecombe $(1989)$, where $\left(v+\lambda_{\mathrm{N}, \mathrm{Na}}+v-\lambda_{\mathrm{N}, \mathrm{OII}}\right)$ was given as $0.0175+0.103=0.1205$. The term $\mu_{\mathrm{N}, \mathrm{N}, \mathrm{Na}}$ was given as -0.000311 ; no second order interaction term was given for $\mu_{\mathrm{N}, \mathrm{N}, \mathrm{OH}}$. Equation (7) was used to calculate the self-interaction parameter for ammonia. Even better agreement was obtained using interaction parameters for sodium hydroxide calculated from the data of Dawson and McCrae (1901), who studied ammonia equilibria through partitioning of ammonia between electrolyte solutions and chloroform. From Dawson and McCrae (1901), the term $\left(v^{+} \lambda_{\mathrm{N}, \mathrm{Na}}+\mathrm{v}-\lambda_{\mathrm{N}, \mathrm{OH}}\right)$ was 0.1320 calculated by Clegg and Brimblecombe (1989). No second order terms were obtained. Ammonia partial pressure data for sodium hydroxide solutions has also been given by Abegg and Reisenfeld (1902), from which Clegg and Brimblecombe calculated the term $\left(v+\lambda_{\mathrm{N}, \mathrm{Na}}+v-\lambda_{\mathrm{N}, \mathrm{OH}}\right)$ as 0.1035 . Again, no second order terms were given. Agrecment was the poorest using these latter results. It is noted that Clegg and Brimblecombe (1989) utilized data obtained for a variety of different salts in deriving their recommended values for the sodium and hydroxide ions, not just data corresponding to sodium hydroxide solutions.

Wilson et al. (1980) has also obtained ammonia equilibria for sodium hydroxide solutions. In that study, ammonia partial pressures were determined at $80^{\circ} \mathrm{C}$ using an ammonia-specific electrode for sodium hydroxide concentrations up to 7 molal. In Figure 14, Henry's Law constants calculated from the results of Wilson et al. (1980) are compared to extrapolated results from the present study using the fitted parameters given in Table 4. (Again, experimental data in this study were obtained in the temperature range of 25 to $70^{\circ} \mathrm{C}$.) The results of Wilson ct al. (1980) are in good agreement with present results for a sodium hydroxide concentration of approximatcly 1 molal, but poor agreement for higher sodium hydroxide concentrations. The lack of a lowering of the Henry's Law constant by increased sodium hydroxide concentration indicated by the data Wilson et al. (1980) is contrary to the predictions of the Pitzer ion interaction model, and is probably not correct. 


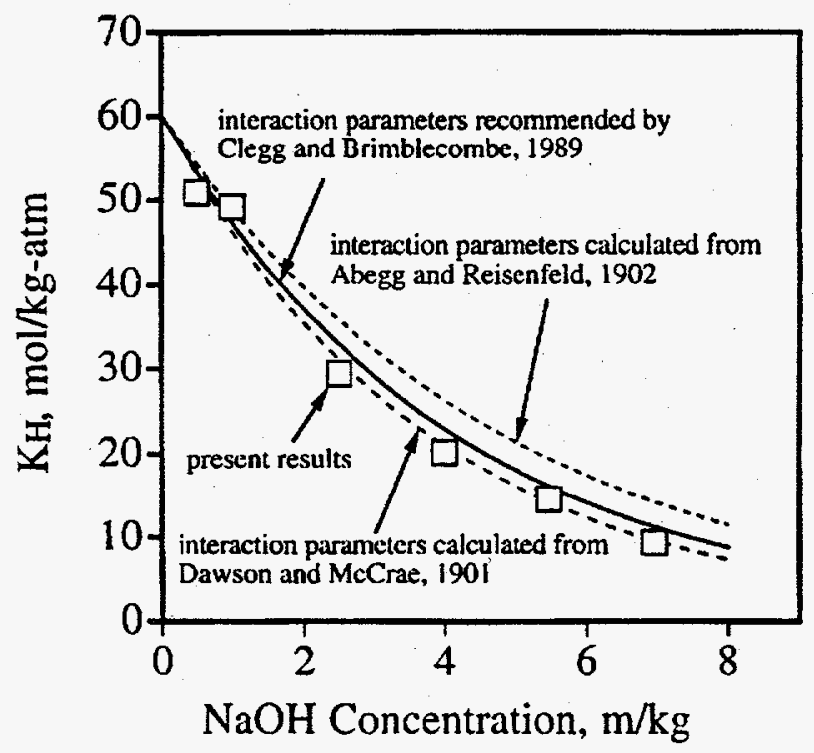

Figure 13. Comparison of Present Henry's Law Constants for Sodium Hydroxide Solutions with Values Calculated Using the Pitzer Ion Interaction Model. Present results were corrected to $25^{\circ} \mathrm{C}$ using the parameters given in Table 4 .

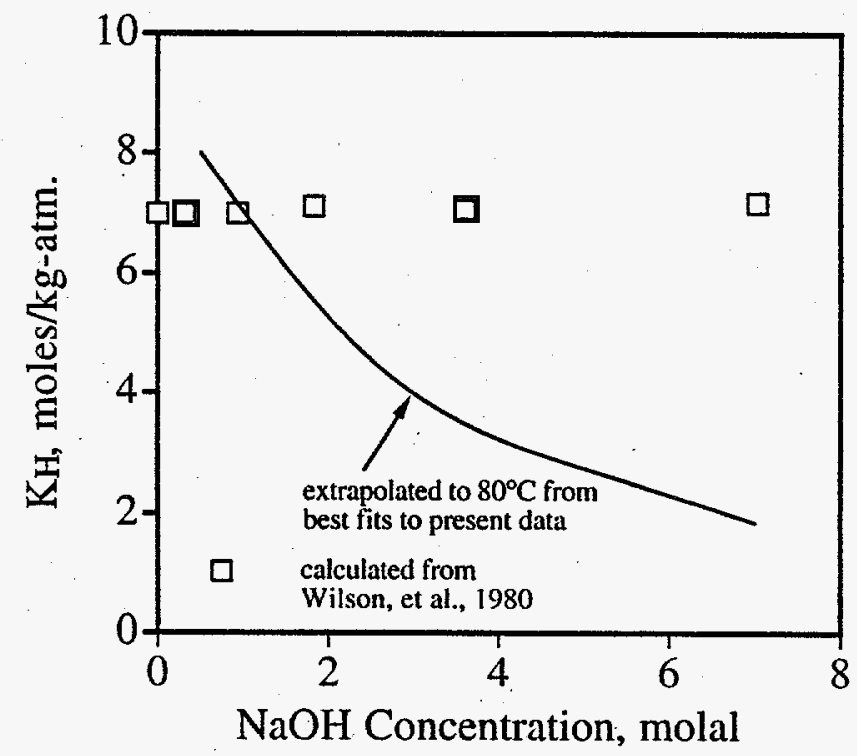

Figure 14. Comparison of Present Henry's Law Constants for Sodium Hydroxide Solutions with Values Calculated from the Data of Wilson et al. (1980). Present results were extrapolated to $80^{\circ} \mathrm{C}$ using the parameters given in Table 4. 
Pederson and Bryan (1994) also have used an ammonia-selective electrode to evaluate ammonia equilibria in a simulated waste mixture. The simulant SY1-SIM-92A was used in that study, which is similar to SY1-SIM-91A but additionally contains certain transition metal nitrates and other minor components (Bryan and Pederson 1994). Known quantities of ammonia were introduced into the simulant at $25^{\circ} \mathrm{C}$. The electrode was suspended above the liquid in a sealed vessel, which resulted in the most consistent readings. Identical readings were obtained for dilute standard solutions whether the electrode was submersed in the liquid or suspended above the liquid. For identical aqueous ammonia concentrations per liter of solution for the simulant and for water (adjusted to $\mathrm{pH} 12$ ), ammonia readings obtained by Pederson and Bryan (1994) were approximately a factor of two higher for the simulant than for the dilute solution. Essentially identical Henry's Law constants are estimated for the two solutions: they were, however, expressed in units of moles ammonia in the liquid per kilogram water per atmosphere ammonia partial pressure. This behavior is not consistent with present results showing an inverse relation between Henry's Law constants and electrolyte concentration, nor is it consistent with predictions of the Pitzer ion interaction model. In consideration of the results of both Pederson and Bryan (1994) and of Wilson et al., (1980), it would appear that ammonia equilibria measurements obtained for concentrated electrolytes using an ammoniaselective electrode should be interpreted cautiously.

Henry's Law constants were also calculated for the simulant SY1-SIM-93B following Equations (6) and (7), using ion interaction parameters given by Clegg and Brimblecombe (1989). Interaction parameters that were used in these calculations are given in Table 5. No value for the aluminate ion was available, but was estimated to be equal to that for the hydroxide ion. Temperature dependencies for ion interaction parameters were not available for many of the ions of interest here. Except for ammonia self-interaction, which is given as a function of temperature by Equation (7), ion interaction parameters were assumed to be independent of temperature in these calculations. In consideration of data for other ions that are available (Clegg and Brimblecombe 1989), this assumption should not lead to significant error.

Table 5. Ion Interaction Parameters for Ammonia at $25^{\circ} \mathrm{C}$ Used in Estimating Henry's Law Constants for Simulant SY1-SIM-93B (from Clegg and Brimblccombe 1989)

\begin{tabular}{ll} 
Ion & \multicolumn{1}{c}{$\lambda_{\mathrm{N}, \mathrm{j}}$} \\
\cline { 2 - 2 } $\mathrm{Na}^{+}$ & 0.0175 \\
$\mathrm{OH}^{-}$ & 0.103 \\
$\mathrm{AlO}_{2}^{-}$ & $0.103(\mathrm{a})$ \\
$\mathrm{NO}_{3}^{-}$ & -0.01 \\
$\mathrm{NO}_{2}^{-}$ & -0.003 \\
$\mathrm{CO}_{3}{ }^{-}$ & 0.180
\end{tabular}

(a) This value is an estimate; no data was available for the aluminate ion. 
At the lower end of the temperature range used in the present study $\left(25\right.$ to $\left.40^{\circ} \mathrm{C}\right)$, experimentally determined Henry's Law constants for the simulant SY1-SIM-93B were in very good agreement with values calculated using the ion interaction model, as is shown in Figure 15. Experimentally determined values tended to be slightly higher than those calculated from the ion interaction model at higher temperatures. There are a number of possible contributors to a lack of perfect agreement. Probably the most important is the assumption that ion interaction parameters are temperature-independent in the experimental temperature range. Also, Henry's Law constants for ammonia/water, defined in Equation (4) and on which calculations using the ion interaction model are based, was considered valid for the temperature range 0 to $40^{\circ} \mathrm{C}$, where present calculations extend to $70^{\circ} \mathrm{C}$.

Similar comparisons for the simulant SY1-SIM-91A were not made because of the changing solution composition with increased temperature. Data on how the liquid phase evolved with temperature for this simulant were not obtained. Equations describing the solubilities of components in the system sodium nitrate/sodium nitrite/sodium hydroxide/sodium carbonate/sodium aluminate/water have been developed by Reynolds and Herting (1984), however, which could prove useful in calculating Henry's Law constants using the ion interaction model.

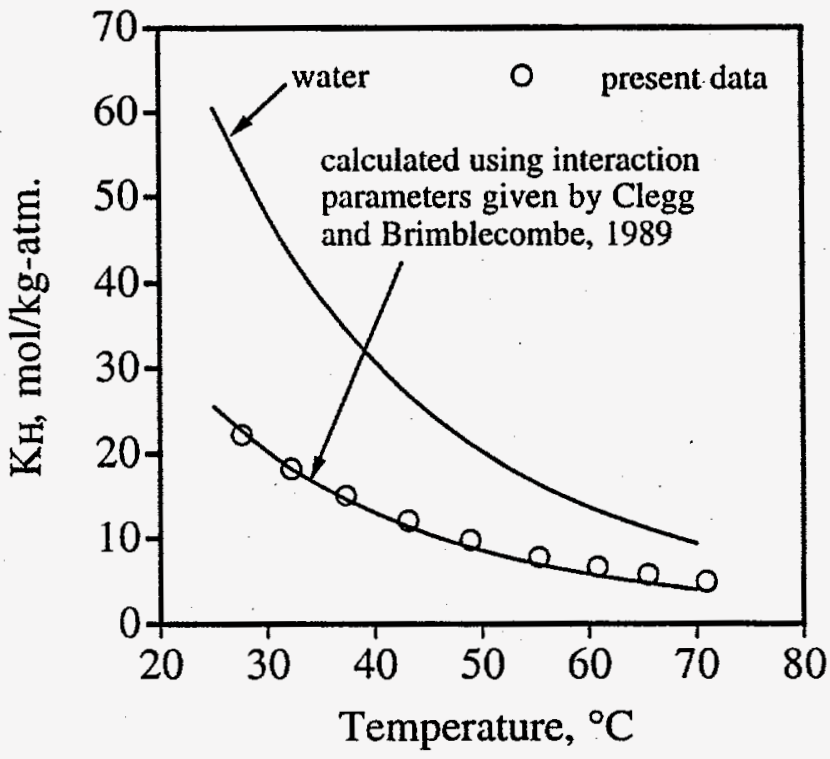

Figure 15. Comparison of Henry's Law Constants Determined for the Simulant SY1-SIM-93B with Values Calculated from the Pitzer Ion Interaction Model, Using Interaction Parameters Given by Clegg and Brimblecombe (1989). 


\subsection{Estimation of Aqueous Ammonia Content in Tank 241-SY-101}

From the composition of gases released from Tank 241-SY-101, the composition of wastes in that tank, the temperature of the wastes, and ammonia equilibria results determined as a result of this study, the concentration of aqueous ammonia in the wastes may be estimated. It is assumed here that Henry's Law constants determined for the slurry simulant SY1-SIM-91A is applicable for actual wastes, corrected only for the fraction of water present.

Ammonia is one of the principal components of gases found during a Gas Release Event (GRE). The best estimate of its concentration is 10.95 mole percent, while a conservative estimate of 14.95 mole percent has been given (U.S. Department of Encrgy 1994). A reasonable estimate for the hydrostatic pressure in the non-convecting layer where gases were retained and released (prior to the emplacement of a mixer pump) in Tank 241-SY-101 is 2 atmospheres (Babad et al. 1991; Babad et al. 1992). Thus, the expected partial pressure of ammonia in gas bubbles retained in the nonconvecting layer is $2 \mathrm{~atm}$. $x 11$ mole percent $=0.22 \mathrm{~atm}$. Of course, this calculation assumes that the composition of released gases given by the U.S. Department of Energy (1994) reflects the composition of those held in the non-convecting layer; the GRE is believed to occur sufficiently fast that no changes in composition of the gases can occur through interaction with wastes found at the top of the tank, which may contain a larger water mole fraction and be somewhat cooler (Reynolds 1992; Allemann et al. 1993).

The fraction of water that is present in the stored wastes is an important consideration when relating ammonia partial pressure to aqueous ammonia concentration. Water fractions determined during Window $\mathrm{C}$ ranged from a low of approximately 19 wcight percent for the lower sludge layer (room temperature gravimetric method) to a high of more than 46 weight percent for the upper convecting layer (thermogravimetric method) (Herting et al. 1992a; Reynolds 1992). The water content for composite samples are 38.0 and 35.5 weight percent for Window $\mathrm{C}$ and Window $\mathrm{E}$, respectively (Herting et al. 1992a; Herting et al. 1992b; Reynolds 1992).

The partial pressure of ammonia for a given solution containing aqueous ammonia is sensitive to temperature. Before emplacement of the mixer pump, considerable stratification in the temperature profiles of the wastes were observed. Reynolds (1992) has shown the non-convecting layer temperature to be approximately $54^{\circ} \mathrm{C}$, while the convecting layer temperature was approximately $50^{\circ} \mathrm{C}$. Non-convecting layer temperatures of as much as $60^{\circ} \mathrm{C}$ have been seen (Allemann et al. 1993).

The simulant SY1-SIM-91A, while being a saturated solution of the principal inorganic components known to be present in actual wastes, does not match the complexity of actual wastes. Actual wastes are known to contain a varicty of transition metal salts, noble metals, phosphate, sulphate, fluoride, and chloride, in addition to a varicty of organic complexants, buffering agents, and degradation products (Herting et al. 1992a; Herting et al. 1992b; Campbell et al. 1994). Ion interaction parameters are not known for many of these additional components of actual wastes, which somewhat complicates an estimate of their contribution to ammonia equilibria bchavior. Despite the shortcomings of the use of waste simulants, the composition of simulant SY1-SIM-91A is sufficiently similar to actual wastes to allow a reasonable approximation of actual waste behavior.

Using the best fit parameters to define the Henry's Law constant for the simulant SY1-SIM-91A:

$$
\ln \left(\mathrm{K}_{\mathrm{H}(\mathrm{SY} 1-\mathrm{SIM}-91 \mathrm{~N})}=-7.577+2571.3 / \mathrm{T}(\mathrm{K})+0.003076 \mathrm{~T}(\mathrm{~K})\right.
$$


the concentration of aqucous ammonia as a function of temperature and water content of the wastes can be calculated, the results of which are shown in Figure 16. Calculated results are additionally given in Appendix B, Table B.10. If the gases released during a GRE originate from the nonconvecting layer whose temperature was $60^{\circ} \mathrm{C}$ with a water content of 30 weight percent, it is estimated that the aqueous ammonia concentration is 0.37 weight percent. If the non-convecting layer contained only 20 weight percent water, the estimated aqueous ammonia content is 0.24 weight percent. The aqueous ammonia content reported from Window E (Herting et al. 1992b) was 0.2 weight percent. It is not known whether the sample was preserved to prevent ammonia loss prior to analysis, however, so that value could be somewhat low.

Gas bubbles that slowly rise from the non-convecting layer through the convecting layer to the surface are expected to evolve with respect to the ammonia content. As the bubble rises, the hydrostatic pressure will fall from 2 atmospheres to 1 atmosphere. This would cause the ammonia partial pressure to be below the equilibrium value. To re-establish equilibrium, the gas bubble will extract ammonia vapor from the liquid phase. The mole fraction of ammonia in slowly released gas bubbles should thus be higher than rapidly released gases. The temperature of the convecting layer is lower than that of the non-convecting layer, however, so the equilibrium vapor pressure for a given concentration of ammonia per kilogram water would be lowered, partially offsetting the effects of pressure lowering. In addition, the cooler convecting liquids will contain smaller concentrations of dissolved electrolytes, which will lower the equilibrium ammonia partial pressure. The effects of pressure should still dominate, however, so slowly released gases should contain higher mole fractions of ammonia than those rcleased instantancously.

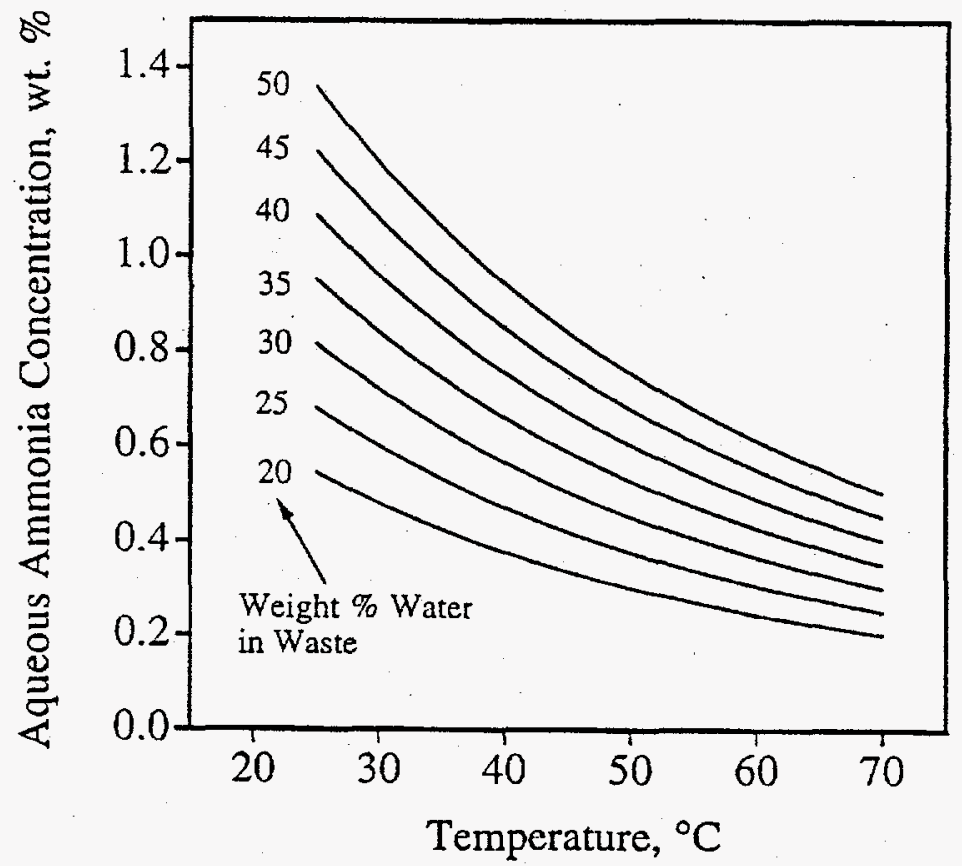

Figure 16. Estimated Aqueous Ammonia Concentrations in Weight Percent as a Function of Temperature for Several Different Concentrations of Water in the Wastes. Henry's Law constants were calculated from the best fit to present experimental data, following Equation (8). 


\subsection{Surface Tension by the Maximum Bubble Pressure Method}

The liquid/vapor surface tensions of sodium hydroxide solutions, sodium nitrate solutions, and the waste simulant compositions SY1-SIM-93B and SY1-SIM-91A were determined as a function of temperature using the maximum bubble pressure method originally described by Sugden (1922). The role of additives including ammonia and various organic compounds on surface tension were evaluated, as was the effect of gas bubble identity on surface tension. Among the advantages of the maximum bubble pressure method are independence of solid/liquid contact angle, for contact angles less than $90^{\circ}$, being amenable to measurements involving corrosive liquids, and being relatively insensitive to liquid density. Liquid/vapor surface tension is one of the parameters that are important in controlling the morphology of gas bubbles trapped in the wastes. High surface tension values favor spherically-shaped gas bubbles, which would provide the lowest liquid/vapor interfacial area. When the surface tension is lowered, dendritic bubbles may be formed, which can deform to fill pores between solid particles (Allcmann et al. 1993). The response of gas bubble/solid particle assemblages to acoustic waves is also affected by surface tension (Cannon 1994).

\subsection{Surface Tension of Sodium Hydroxide, Sodium Nitrate, and Simulant Solutions}

The surface tension of aqueous solutions of sodium hydroxide and sodium nitrate and of simulant mixtures were evaluated as a function of temperature in the range 10 to $80^{\circ} \mathrm{C}$. In general, surface tension values increased with increased clectrolyte concentration and decreased with temperature, as is well-known (CRC Handbook of Chemistry and Physics 1990; Perry and Green 1984). Results for sodium hydroxide and sodium nitrate solutions are given in Figures 17 and 18, respectively. Data for sodium hydroxide and sodium nitrate solutions are given in Appendix C, Tables C.1

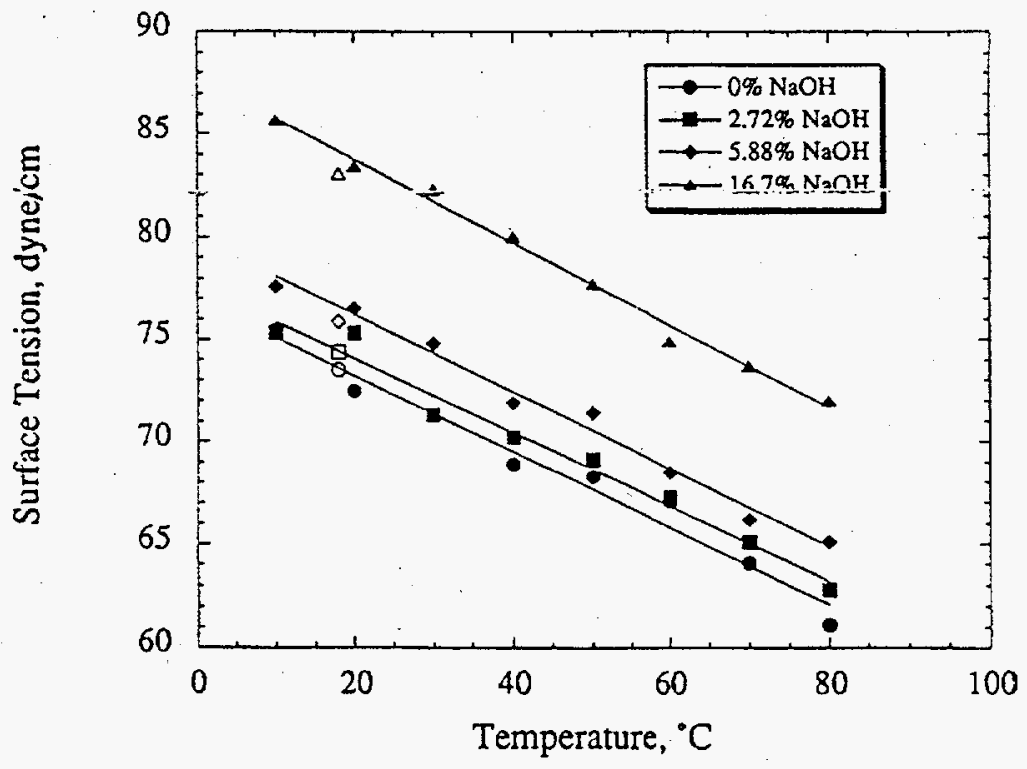

Figure 17. Surface Tension of Sodium Hydroxide Solutions as a Function of Temperature 


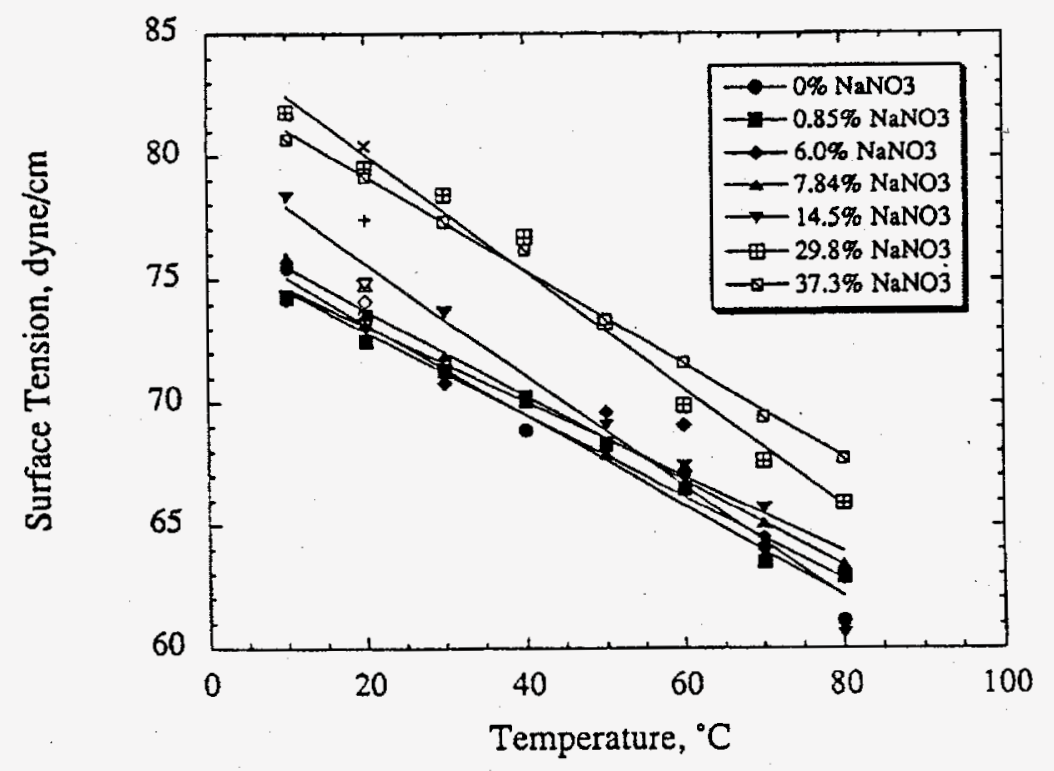

Figure 18. Surface Tension of Sodium Nitrate Solutions as a Function of Temperature

and C.2, respectively. Surface tension values for the simulant mixtures are given in Figure 19. As expected, highest values were found for the more concentrated simulant SY1-SIM-91A. Solid lines in Figures 17,18 , and 19 correspond to a least squares fit of the form: $\gamma=\mathrm{a}-\mathrm{bT}\left({ }^{\circ} \mathrm{C}\right)$ (Perry and Green 1984). These fitted parameters are listed in Table 6.

\subsection{Effect of Ammonia on the Surface Tension of Simulated Wastes}

The liquid/vapor surface tension of the waste simulant mixtures was significantly lowered by the addition of aqueous ammonia. As is shown in Figure 20, the addition of 1 weight percent aqueous ammonia lowered the surface tension of the simulant SY1-SIM-93B from approximately 83 dynes/ $\mathrm{cm}$ to 78 dynes $/ \mathrm{cm}$ at $30^{\circ} \mathrm{C}$. Data corresponding to Figure 20 is listed in Appendix C, Table C.3. Further decreases were noted when the aqueous ammonia content was increased to 2 weight percent. As the temperature was raised, ammonia was less effective in lowering the surface tension for this simulant.

Ammonia was much more effective in lowering the surface tension of the slurry simulant SY1-SIM-91A, as shown in Figure 21. Data corresponding to Figure 21 are given in Appendix C, Table C.4. Whereas the surface tension of this simulant with no ammonia present was nearly 100 dynes $/ \mathrm{cm}$ at $50^{\circ} \mathrm{C}$, a 1 weight percent addition of aqueous ammonia reduced that value to less than 70 dynes $/ \mathrm{cm}$. This value is not only less than obtained for the homogeneous simulant, but is even equal to or less than pure water. The addition of only 1 weight percent of aqueous ammonia is sufficient to offset the effects of approximately 60 weight percent of various sodium salts, a surprising result. 


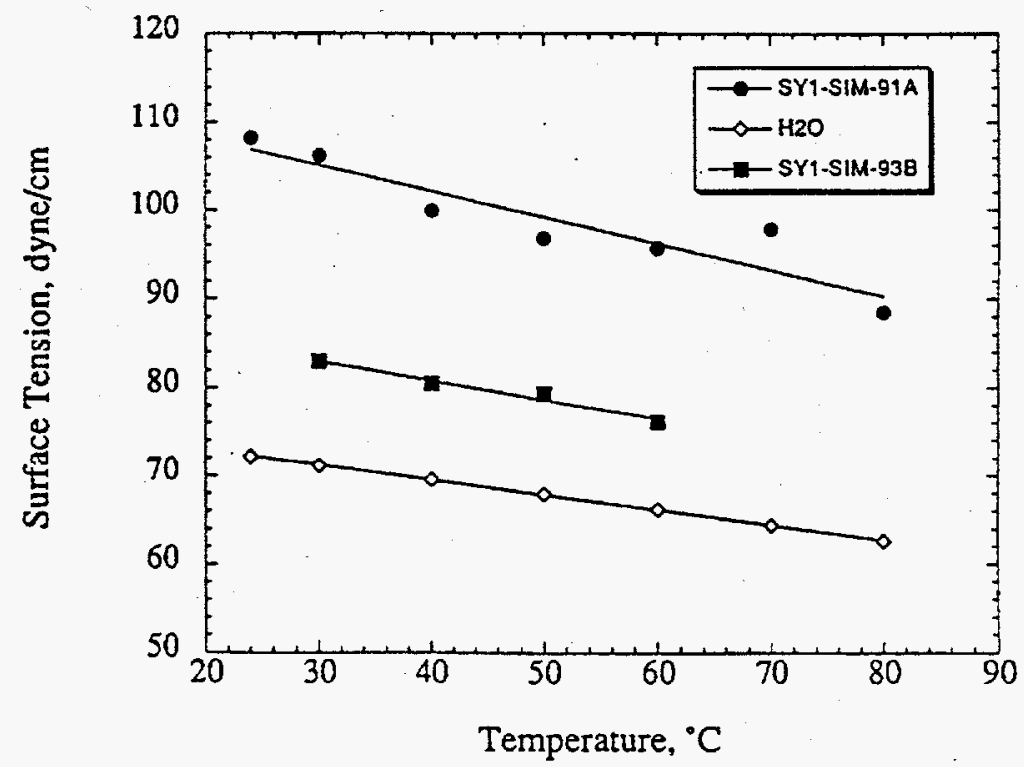

Figure 19. Surface Tension of Simulant Mixtures SY1-SIM-91A and SY1-SIM-93B as a Function of Temperature

Table 6. Fitted Constants for Temperature Dependence of Surface Tension of Sodium Hydroxide, Sodium Nitrate, and Waste Simulants SY1-SIM-93B and SY1-SIM-91A; $\gamma=\mathrm{a}-\mathrm{bT}\left({ }^{\circ} \mathrm{C}\right)$; Temperature Range 10 to $80^{\circ} \mathrm{C}$

\begin{tabular}{crc} 
Solution & \multicolumn{1}{c}{$a$} & $b$ \\
$18 \mathrm{M} \Omega-\mathrm{cm} \mathrm{H} \mathrm{O}$ & & \\
$2.72 \mathrm{wt} \% \mathrm{NaOH}$ & 77.45 & 0.1850 \\
$5.88 \mathrm{wt} \% \mathrm{NaOH}$ & 79.99 & 0.1805 \\
$16.7 \mathrm{wt} \% \mathrm{NaOH}$ & 87.76 & 0.1886 \\
$0.085 \mathrm{wt} \mathrm{NaNO}_{3}$ & 76.23 & 0.1679 \\
$5.89 \mathrm{wt} \mathrm{NaNO}_{3}$ & 76.17 & 0.1530 \\
$7.84 \mathrm{wt} \% \mathrm{NaNO}_{3}$ & 77.24 & 0.1736 \\
$14.5 \mathrm{wt} \% \mathrm{NaNO}_{3}$ & 80.14 & 0.2256 \\
$29.8 \mathrm{wt} \% \mathrm{NaNO}_{3}$ & 84.84 & 0.2377 \\
$37.3 \mathrm{wl} \% \mathrm{NaNO}_{3}$ & 82.93 & 0.1892 \\
SY1-SIM-93B & 89.40 & 0.2150 \\
SY1-SIM-91A & 112.46 & 0.8017
\end{tabular}




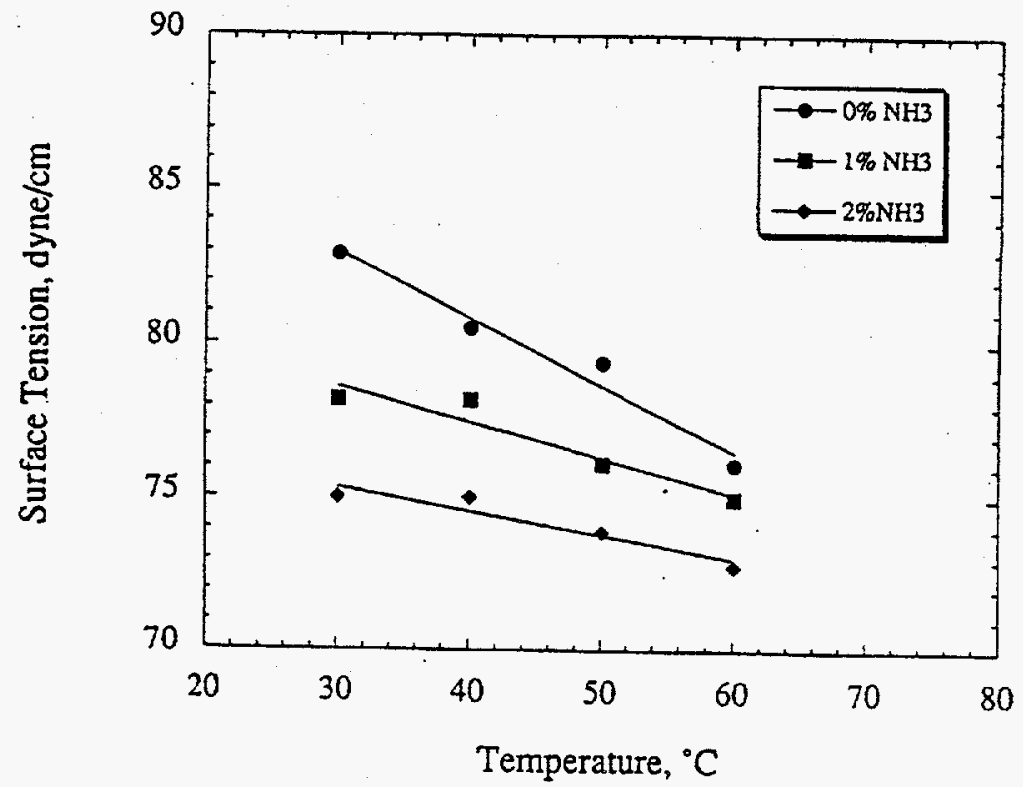

Figure 20. Surface Tension of the Simulant SY1-SIM-93B as a Function of Temperature with and Without Aqueous Ammonia Added

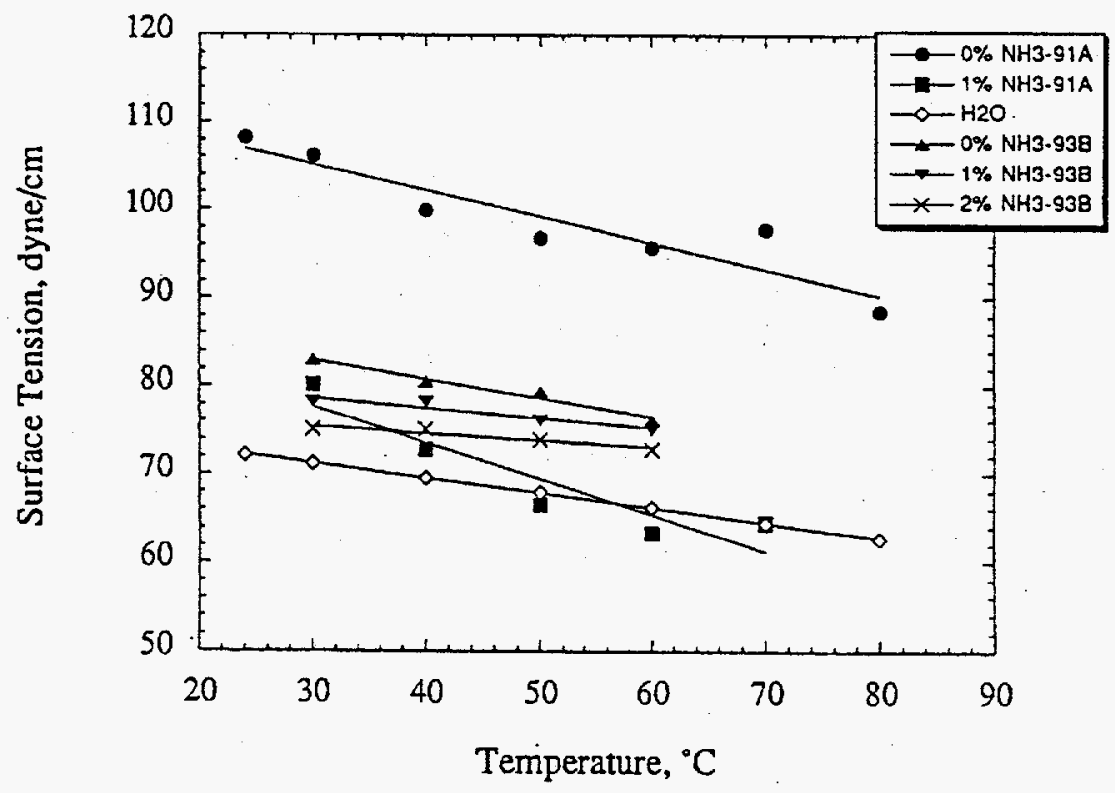

Figure 21. Surface Tension of the Simulants SY1-SIM-91A and SY1-SIM-93B as a Function of Temperature with and Without Aqueous Ammonia Added 
Ammonia equilibria behavior for the two simulants used in this study are also quite different and relate to surface tension changes. At $50^{\circ} \mathrm{C}$, as described above, the Henry's Law constant for ammonia in simulant SY1-SIM-93B is approximately twice that for ammonia in simulant SY1-SIM91A, expressed in units of moles ammonia per kilogram water per atmosphere. In addition, the homogeneous simulant contains substantially more water than the slurry simulant (see Tables 1 and 2), so has a larger capacity to retain ammonia in the liquid phase. Thus, for a given aqueous ammonia concentration expressed in weight percent, the ammonia partial pressure corresponding to SY1SIM-91A should be approximately three to five times higher than found for SY1-SIM-93B. For ammonia to act as an effective surfactant, it must segregate to the liquid/vapor interface, thereby lowering the surface tension. The concentrated simulant has less capacity to retain ammonia in the aqueous phase, thereby raising the extent of segregation to the liquid/vapor interface and raising the concentration of ammonia in the vapor.

\subsection{Effect of Added Organics and Effect of Gas Identity on the Surface Tension of Simulated Wastes}

In contrast to the substantial effects of ammonia additions, measured surface tension values of homogeneous simulant SY1-SIM-93B were relatively unaffected by the addition of organics, or by the identity of the gas used in maximum bubble pressure measurements. Surface tension results for the addition of sodium salts of citric acid, formic acid, glycine, EDTA and HEDTA corresponding to 1.5 weight percent total organic carbon are summarized in Appendix C, Table C.5, and in Figure 22. Within experimental scatter, no effect of organic component addition on surface tension was obvious. Simple organic molecules often lower the surface tension of water in small concentrations, though this is not always true (Vold and Vold 1983; CRC Handbook of Chemistry and Physics 1990). None of the organic salts included in this study contain distinctly non-polar functional groups that could be aligned towards the vapor/liquid interface and thereby be highly surface active (such as sodium dodecyl sulfate, a well-known surfactant). In caustic solutions of high ionic strength, organic compounds used in this study are likcly to be present as ion pairs, not as molecules with charged functional groups (Robinson and Stokes 1959), which would further diminish their ability to affect surface tension behavior.

The measured surface tension of the simulant SY1-SIM-93B was unaffected by the identity of the gas that was used to form bubbles in the maximum bubble pressure apparatus. As shown in Appendix $\mathrm{C}$, Table C.6, identical surface tension values were obtained whether $\mathrm{N}_{2}, \mathrm{O}_{2}, \mathrm{H}_{2}, \mathrm{~N}_{2} \mathrm{O}$ or $\mathrm{CH}_{4}$ was used in the measurements. With the exception of $\mathrm{N}_{2} \mathrm{O}$, the gases are essentially spherically symmetrical; segregation to the liquid/vapor interface would not change the character of that interface. Nitrous oxide, a non-linear molecule (Cotton and Wilkinson 1980), could possibly segregate to the interface in an aligned manner. This gas exhibits the highest solubility in water of those used here (CRC Handbook of Chemistry and Physics 1990; Young 1981). Present data indicate, at least in concentrated electrolyte solutions, that this does not occur. Although not included in this study, ammonia usage certainly would lead to different (lower) measured surface tension values. 


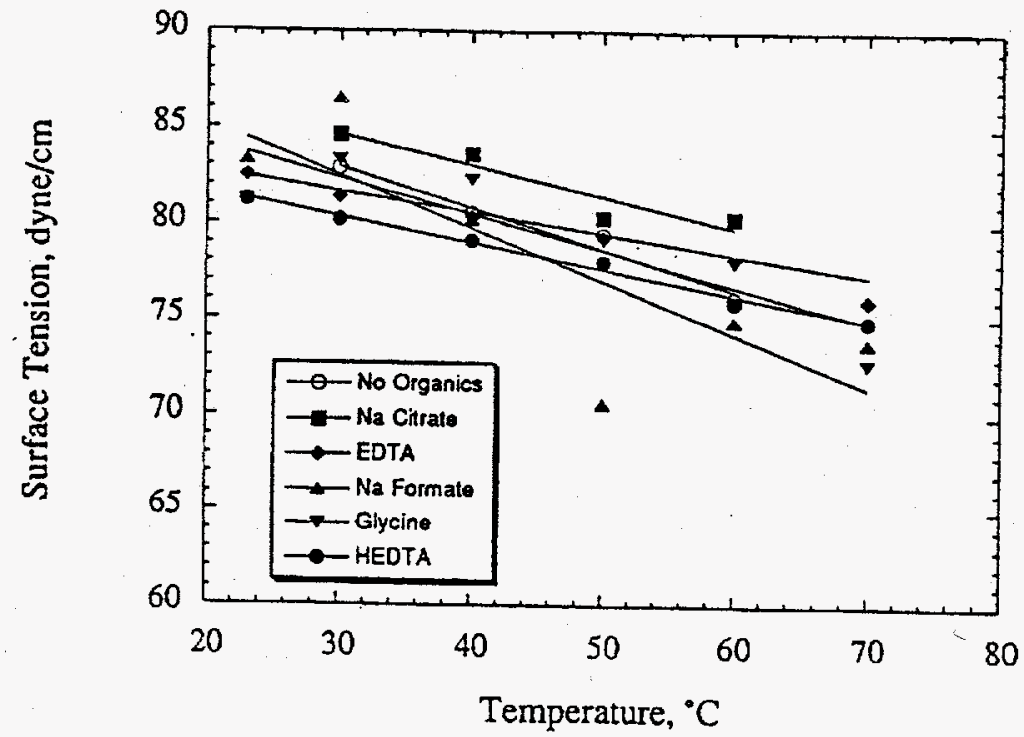

Figure 22. Surface Tension of Simulant SY1-SIM-93B Containing Various Organic Additives in Concentrations Corresponding to 1.5 Weight Percent Total Organic Carbon 


\subsection{Summary and Conclusions}

In this study, ammonia equilibria behavior in simulated Hanford double-shell tank wastes and in sodium hydroxide solutions has been examined as a function of electrolyte concentration and temperature. From these data, expressions for Henry's Law constants were derived. Experimentally determined values were compared with Henry's Law constants calculated using the Pitzer ion interaction model and ion interaction parameters obtained from the literature, with generally very good agreement. These results can be used to estimate the concentration of aqueous ammonia that is present in actual tank wastes. Surface tension values for sodium hydroxide solutions, sodium nitrate solutions, and simulated waste mixtures were also determined. The effects of ammonia and certain organic compound addition on surface tension properties were examined.

Equilibrium ammonia partial pressures for simulated waste mixtures were substantially higher than for dilute solutions containing identical concentrations of aqueous ammonia. This effect was most pronounced for the simulant SY1-SIM-91A, a slurry. For sodium hydroxide solutions, ammonia vapor pressures rose steadily with increased sodium hydroxide concentration, for a fixed aqueous ammonia concentration. Experimentally determined ammonia partial pressures are in reasonably good agreement with those calculated using Pitzer interaction coefficients for both sodium hydroxide solutions and for the simulant SY1-SIM-93B. No attempt was made to model the behavior of the slurry simulant SY1-SIM-91A, where the concentration of dissolved electrolytes changes with temperature. Organic compounds were excluded from the waste simulants in this study to simplify interpretation of the data (degradation reactions involving organics could result in ammonia formation). They should be considered in future studies, however.

Expressions for Henry's Law constants for simulated waste mixtures and for sodium hydroxide solutions were calculated from the present data. For the simulant SY1-SIM-93B, a homogeneous simulant, Henry's Law constants are, in units of moles ammonia per kilogram water per atmosphere ammonia:

$$
\ln \left(\mathrm{K}_{\mathrm{H}(\mathrm{SY} 1-\mathrm{SIM}-93 \mathrm{~B})}\right)=-7.357+3330.1 / \mathrm{T}(\mathrm{K})-0.002139 \mathrm{~T}(\mathrm{~K})
$$

For the simulant SY1-SIM-91A, a heterogeneous (slurry) simulant, the expression is:

$$
\ln \left(\mathrm{K}_{\mathrm{H}(\mathrm{SY} 1-\mathrm{SIM}-91 \mathrm{~A})}\right)=-7.577+2571.3 / \mathrm{T}(\mathrm{K})+0.003076 \mathrm{~T}(\mathrm{~K})
$$

It is possible to estimate the concentration of aqueous ammonia that was present in the nonconvecting layer at the time of a GRE, using Henry's Law constants determined in this study for the slurry simulant SY1-SIM-91A and knowing the temperature and water content of the wastes. Of course, it should be recognized that the simulant SY1-SIM-91A is much simpler in composition than the actual tank wastes. The simulant does contain the principal inorganic components of actual wastes, however, so should provide a reasonable approximation of actual waste bchavior. An estimate of 0.6 weight percent aqueous ammonia was made assuming a water content of 40 weight percent and a temperature of $50^{\circ} \mathrm{C}$. Higher temperatures and lower water content in the non-convecting layer would lower the estimated aqueous ammonia content. For example, if the water content in the nonconvecting layer was 30 weight percent and the temperature was $60^{\circ} \mathrm{C}$, an aqueous ammonia concentration of 0.37 weight percent is estimated. This estimate would also be lowered if the composition of gases released from the non-convecting layer was not preserved as the gases proceeded to the top of the wastes. Gas bubbles that rise slowly to the top of the wastes will extract ammonia gas from the 
liquid to re-establish the equilibrium ammonia partial pressure as the overall pressure falls, resulting in a higher mole fraction of ammonia than those released instantancously.

Liquid/vapor surface tension values are needed for modelling waste bchavior. In particular, surface tension is one of the key parameters that determines the morphology of gas bubbles retained in tank wastes - whether those bubbles will be spherical in shape or dendritic. Ammonia was found to be the most surface-active of the components known to be present in actual tank wastes. A one weight percent addition of aqueous ammonia lowered the surface tension of the simulant SY1-SIM$91 \mathrm{~A}$ at $50^{\circ} \mathrm{C}$ from approximately 100 dynes $/ \mathrm{cm}$ to less than 70 dynes $/ \mathrm{cm}$, which is similar to the surface tension of pure water at that temperature. Similar but smaller effects were noted for the homogeneous simulant SY1-SIM-93B. Thus, this relatively small ammonia addition was sufficient to offset the effects of approximately 60 weight percent of dissolved clectrolytes. 


\subsection{References}

Abegg, R., and H. Reisenfeld. 1902. Z. Phys. Chem. 40:84.

Allemann, R. T., T. M. Burke, D. A. Reynolds, and D. E. Simpson. 1993. Assessment of Gas Accumulation and Retention - Tank 241-SY-101. WHC-EP-0576, Westinghouse Hanford Company, Richland, Washington.

Ashby, E. C., C. Jonah, D. Meisel, L. R. Pederson, and D. M. Strachan. 1992. Gas Generation and Retention in Tank 241-SY-101: A Summary of Laboratory Studies, Tank Data, and Information Needs. PNL-8124, Pacific Northwest Laboratory, Richland, Washington.

Ashby, E. C., F. Doctorovich, C. L. Liotta, H. M. Neumann, E. K. Barefield, A. Konda, K. Zhang, J. Hurley, and D. D. Siemer. 1993. "Concerning the Formation of Hydrogen in Nuclear Waste. Quantitative Generation of Hydrogen via A Cannizzaro Intermediate." J. American Chemical Society 115:1171.

Ashby, E. C., E. K. Barefield, C. L. Liotta, H. M. Neumann, F. Doctorovich, A. Konda, K. Zhang, J. Hurley, D. Boatwright, D. A. Annis, G. Pansino, M. Dawson, and M. Juliao. 1994. "Mechanistic Studies Related to the Thermal Chemistry of Simulated Wastes Which Mimic Contents of Tank 101SY." American Chemical Society Symposium Series 554:249-284.

Babad, H., G. D. Johnson, J. A. Lechelt, D. A. Reynolds, L. R. Pederson, D. M. Strachan, D. Meisel, C. D. Jonah, and E. C. Ashby. 1991. Evaluation of the Generation and Release of Flammable Gases in Tank 241-SY-101. WHC-EP-0517, Westinghouse Hanford Company, Richland, Washington.

Babad, H., G. D. Johnson, J. A. Lechelt, D. A. Reynolds, and D. M. Strachan. 1992. Understanding of Cyclic Venting Phenomena in Hanford Site High-Level Waste Tanks: The Evaluation of Tank 241-SY-101. WHC-SA-1364-FP, Westinghouse Hanford Company, Richland, Washington.

Barney, G. S. 1976. Vapor-Liquid-Solid Phase Equilibria of Radioactive Sodium Salt Wastes at Hanford. ARH-ST-133, Atlantic Richficld Company, Richland, Washington.

Bryan, S. A., L. R. Pederson, and R. D. Scheele. 1992. "Crust Growth and Gas Retention in Synthetic Hanford Wastes." In Waste Management '92. R. G. Post and M. E. Wacks, Eds., American Nuclear Society and International Atomic Energy Agency 1:829-834.

Bryan, S. A., L. R. Pederson, R. D. Scheele, and S. R. Adami. 1993. In Proceedings of the 4th Annual International Conference on High Level Radioactive Waste Management, 2:1348, American Nuclear Society, Las Vegas, Nevada.

Bryan, S. A., and L. R. Pederson. 1994. Composition, Preparation, and Gas Generation Results from Simulated Wastes of Tank 241-SY-101. PNL-10075, Pacific Northwest Laboratory, Richland, Washington. 
Campbell, J. A., S. Clauss, K. Grant, V. Hoopes, B. Lerner, P. Lucke, G. Mong, J. Rau, and R. Steele. 1994. Flammable Gas Safety Program, Analytical Methods Development: FY 1993 Progress

Report. PNL-9062, Pacific Northwest Laboratory, Richland, Washington.

Cannon, N. S. 1994. 101-SY Waste Sample Speed of Sound/Rheology Testing for Sonic Probe Program. WHC-SD-WM-DTR-034, Westinghouse Hanford Company, Richland, Washington.

Clegg, S. L., and P. Brimblecombe. 1989. "Solubility of Ammonia in Pure Aqueous and Multicomponent Solutions." Journal of Physical Chemistry 93:7237-7248.

Cotton, F. A., and G. Wilkinson. 1980. Advanced Inorganic Chemistry, John Wiley and Sons, New York, p. 407.

CRC Handbook of Chemistry and Physics. 1990. 71st edition, CRC Press, Boca Raton, Florida, p. 6-102.

Dawson, H. M., and J. J. McCrae. 1901. J. Chem. Soc. 79:493.

Edwards, T. J., G. Maurer, J. Newman, and J. M. Prausnitz. 1978. "Vapor-Liquid Equilibria in Multicomponent Aqueous Solutions of Volatile Weak Electrolytes." American Institute of Chemical Engineering Journal 24:966-976.

Herting, D. L., D. B. Bechtold, B. A. Crawford, T. L. Welsh, and L. Jensen. 1992a. Laboratory Characterization of Samples Taken in May 1991 from Hanford Waste Tank 241-SY-101. WHC-SDWM-DTR-024 Rev 0, Westinghouse Hanford Company, Richland, Washington.

Herting, D. L., D. B. Bechtold, B. E. Hey, B. D. Keele, L. Jensen, and T. L. Welsh. 1992b. Laboratory Characterization of Samples Taken in December 1991 (Window E) from Hanford Waste Tank 241-SY-101. WHC-SD-WM-DTR-026 Rev 0, Westinghouse Hanford Company, Richland, Washington.

Meisel, D., C. D. Jonah, S. Kapoor, M. S. Matheson, and M. C. Sauer, Jr. 1993. Radiolytic and Radiolytically Induced Generation of Gases From Synthetic Wastes. ANL-93/43, Argonne National Laboratory, Argonne, Illinois.

Pederson, L. R., and S. A. Bryan. 1994. Assessment of the Potential for Ammonium Nitrate Formation and Reaction in Tank 241-SY-101. PNL-10067, Pacific Northwest Laboratory, Richland, Washington.

Perry, R. H., and D. Green. 1984. Perry's Chemical Engineering Handbook, 6th Edition, McGraw Hill, New York, p. 3-73.

Pitzer, K. S. 1973a. J. Phys. Chem. 77:268.

Pitzer, K. S. 1973b. J. Phys. Chem. 77:2300.

Pitzer, K. S. 1979. Activity Coefficients in Electrolyte Solutions, R. M. Pytkowicz, Ed., CRC Press, Boca Raton, Florida, 1:209.

Pitzer, K. S. 1987. Reviews in Mineralogy 17:97. 
Pourbaix, M. 1974. Atlas of Electrochemical Equilibria. National Association of Corrosion Engineers, Houston, Texas, p. 168.

Robinson, R. A., and R. H. Stokes. 1959. Electrolyte Solutions, 2nd ed., Academic Press, New York. Schumpe, A. 1993. "The Estimation of Gas Solubilities in Salt Solutions." Chem. Eng. Sci. 48:153158.

Setschenow, J. 1889. Z. Phys. Chem. 4:117.

Sugden, J. 1922. Journal of the American Chemical Society 121:858.

Reynolds, D. A. 1992. Window C Results and Interpretation. WHC-EP-0589, Westinghouse Hanford Company, Richland, Washington.

Reynolds, D. A., and D. L. Herting. 1984. Solubilities of Sodium Nitrate, Sodium Nitrite, and Sodium Aluminate in Simulated Nuclear Waste. RHO-RE-ST-14P, Rockwcll Intemational, Richland, Washington.

Tank Waste Science Panel. 1991. Chemical and Physical Processes in Tank 241-SY-101: A Preliminary Report. PNL-7595, Pacific Northwest Laboratory, Richland, Washington.

U.S. Department of Energy. 1994. A Safety Assessment for Proposed Pump Mixing Operations to Mitigate Episodic Gas Releases in Tank 241-SY-101: Hanford Site, Richland, Washington. LA-UR92-3196, Rev. 9, Los Alamos National Laboratory, Los Alamos, New Mexico.

Vold, R. D., and M. J. Vold. 1983. Colloid and Interface Chemistry, Addison-Wesley Publishing Co., Inc., Reading, Massachusetts.

Wilson, G. M., R. S. Owens, and M. W. Roe. 1980. "Sour Water Equilibria - Ammonia Volatility down to PPM Levels; pH vs. Composition; and Effect of Electrolytes on Ammonia Volatility." Thermodynamics of Aqueous Systems with Industrial Applications. S. A. Newmann, Ed., American Chemical Society Symposium Series Vol. 133, American Chemical Society, New York, pp. 187-226.

Young, C. L. 1981. Oxides of Nitrogen., Volume 8, in Solubility Series. Permagon Press, New York. 


\section{Appendix A}

Sodium Hydroxide Solution Vapor Pressures 


\section{Appendix A}

\section{Sodium Hydroxide Solution Vapor Pressures}

Table A.1. Water Partial Pressures for 0.50 Molal Sodium Hydroxide Containing 0.00 Molal Aqueous Ammonia

Temperature, ${ }^{\circ} \mathrm{C}$

26.6

31.7

37.5

42.7

48.8

53.1

58.5

65.5

71.0
Water Partial Pressure, atm.

3.57E-02

$4.55 \mathrm{E}-02$

$6.13 \mathrm{E}-02$

8.24E-02

1.093E-01

1.357E-01

$1.758 \mathrm{E}-01$

2.449E-01

$3.126 \mathrm{E}-01$

Table A.2. Water Partial Pressures for 1.00 Molal Sodium Hydroxide Containing 0.00 Molal Aqueous Ammonia

Temperature, ${ }^{\circ} \mathrm{C}$

27.4

32.5

39.1

43.7

48.9

52.7

56.8

61.0

65.8

71.1
Water Partial Pressure, atm.

3.68E-02

4.61E-02

$6.51 \mathrm{E}-02$

$8.36 \mathrm{E}-02$

1.079E-01

$1.283 \mathrm{E}-01$

$1.579 \mathrm{E}-01$

$1.908 \mathrm{E}-01$

$2.388 \mathrm{E}-01$

$3.026 \mathrm{E}-01$

A. 1 
Table A.3. Water Partial Pressures for 2.50 Molal Sodium Hydroxide Containing 0,00 Molal Aqucous Ammonia

\section{Temperature, ${ }^{\circ} \mathrm{C}$}

27.5

32.0

37.3

43.5

49.5

53.1

59.0

63.8

68.9

71.7
Water Partial Pressure, atm.

3.14E-02

4.26E-02

5.91E-02

7.68E-02

1.032E-01

$1.236 \mathrm{E}-01$

1.624E-01

2.045E-01

$2.538 \mathrm{E}-01$

2.907E-01

Table A.4. Wàter Partial Pressures for 3.99 Molal Sodium Hydroxide Containing 0.00 Molal Aqucous Ammonia

Temperature, ${ }^{\circ} \mathrm{C}$

27.7

31.8

37.7

43.1

48.1

51.3

57.9

64.3

69.5
Water Partial Pressure, atm.

$3.07 \mathrm{E}-02$

3.76E-02

4.91E-02

$6.83 \mathrm{E}-02$

8.79E-02

1.107E-01

$1.445 \mathrm{E}-01$

$1.929 \mathrm{E}-01$

$2.438 \mathrm{E}-01$ 
Table A.5. Water Partial Pressures for 5.47 Molal Sodium Hydroxide Containing 0.00 Molal Aqueous Ammonia

\section{Temperature ${ }^{\circ} \mathrm{C}$}

27.7

32.3

37.8

43.0

48.1

54.5

60.6

65.3

71.0
Water Partial Pressure, atm.

$2.84 \mathrm{E}-02$

$3.41 \mathrm{E}-02$

4.58E-02

$6.07 \mathrm{E}-02$

$7.88 \mathrm{E}-02$

$1.095 \mathrm{E}-01$

$1.488 \mathrm{E}-01$

$1.828 \mathrm{E}-01$

2.240E-01

Table A.6. Water Partial Pressures for 6.95 Molal Sodium Hydroxide Containing 0.00 Molal Aqueous Ammonia

\section{Temperature, ${ }^{\circ} \mathrm{C}$}

28.5

32.0

38.1

41.5

49.5

55.1

59.7

64.7

70.7
Water Partial Pressure, atm.

2.8684E-02

3.0000 E-02

5.2237E-02

7.5132E-02

7.8816E-02

$1.0132 \mathrm{E}-01$

1.2697E-01

1.5987E-01

2.1303E-01

A. 3 
Table A.7. Ammonia Partial Pressure, Water Partial Pressure, and Calculated Henry's Law Constants for 0.50 Molal Sodium Hydroxide Solution Containing 0.573 Molal Aqueous Ammonia

\begin{tabular}{|c|c|c|c|c|}
\hline Temperature, ${ }^{\circ} \mathrm{C}$ & $\begin{array}{c}\text { Total Pressure, } \\
\text { atm. }\end{array}$ & $\begin{array}{l}\text { Water Partial } \\
\text { Pressure, atm. }\end{array}$ & $\begin{array}{l}\text { Ammonia Partial } \\
\text { Pressure, atm. }\end{array}$ & $\begin{array}{c}\text { Constant, } \\
\text { mole/kg-atm }\end{array}$ \\
\hline 26.9 & $4.78 \mathrm{E}-02$ & $3.51 \mathrm{E}-02$ & $1.26 \mathrm{E}-02$ & 45.4 \\
\hline 31.6 & $6.00 \mathrm{E}-02$ & $4.56 \mathrm{E}-02$ & $1.44 \mathrm{E}-02$ & 39.9 \\
\hline 38.3 & $8.46 \mathrm{E}-02$ & $6.53 \mathrm{E}-02$ & $1.93 \mathrm{E}-02$ & 29.7 \\
\hline 42.2 & $1.008 \mathrm{E}-01$ & $8.00 \mathrm{E}-02$ & $2.08 \mathrm{E}-02$ & 27.5 \\
\hline 47.5 & $1.293 \mathrm{E}-01$ & $1.044 \mathrm{E}-01$ & $2.50 \mathrm{E}-02$ & 22.9 \\
\hline 52.7 & $1.653 \mathrm{E}-01$ & $1.344 \mathrm{E}-01$ & $3.08 \mathrm{E}-02$ & 18.6 \\
\hline 57.7 & $2.063 \mathrm{E}-01$ & $1.702 \mathrm{E}-01$ & $3.62 \mathrm{E}-02$ & 15.8 \\
\hline 61.5 & $2.468 \mathrm{E}-01$ & $2.026 \mathrm{E}-01$ & $4.43 E-02$ & 12.9 \\
\hline 67.2 & $3.116 \mathrm{E}-01$ & $2.613 \mathrm{E}-01$ & 5.03E-02 & 11.4 \\
\hline 71.3 & $3.660 \mathrm{E}-01$ & $3.121 \mathrm{E}-01$ & $5.38 \mathrm{E}-02$ & 10.6 \\
\hline
\end{tabular}

Table A.8. Ammonia Partial Pressure, Water Partial Pressure, and Calculated Henry's Law Constants for 1.00 Molal Sodium Hydroxide Solution Containing 0.549 Molal Aqueous Ammonia

\begin{tabular}{|c|c|c|c|c|}
\hline Temperature, ${ }^{\circ} \mathrm{C}$ & $\begin{array}{c}\text { Total Pressure, } \\
\mathrm{atm} .\end{array}$ & $\begin{array}{l}\text { Watcr Partial } \\
\text { Pressure, atm. }\end{array}$ & $\begin{array}{l}\text { Ammonia Partial } \\
\text { Pressure, alm. }\end{array}$ & $\begin{array}{c}\text { Henry's Law } \\
\text { Constant, } \\
\text { mole/kg-atm }\end{array}$ \\
\hline 27.3 & $5.03 \mathrm{E}-02$ & $2.43 E-02$ & $2.60 \mathrm{E}-02$ & 28.6 \\
\hline 31.1 & $5.55 \mathrm{E}-02$ & $3.00 \mathrm{E}-02$ & $2.55 \mathrm{E}-02$ & 29.2 \\
\hline 37.9 & $8.12 \mathrm{E}-02$ & 4.33E-02 & $3.79 E-02$ & 19.6 \\
\hline 43.3 & $1.055 \mathrm{E}-01$ & $5.73 \mathrm{E}-02$ & $4.83 \mathrm{E}-02$ & 15.4 \\
\hline 50.5 & $1.496 \mathrm{E}-01$ & $8.19 \mathrm{E}-02$ & $6.77 \mathrm{E}-02$ & 11.0 \\
\hline 57 & $2.016 \mathrm{E}-01$ & $1.117 \mathrm{E}-01$ & $8.99 \mathrm{E}-02$ & 8.3 \\
\hline 61.3 & $2.443 E-01$ & $1.361 \mathrm{E}-01$ & $1.082 \mathrm{E}-01$ & 69 \\
\hline 67.2 & $3.128 \mathrm{E}-01$ & $1.773 \mathrm{E}-01$ & $1.355 \mathrm{E}-01$ & 5.5 \\
\hline 71.2 & $3.740 \mathrm{E}-01$ & $2.109 \mathrm{E}-01$ & $1.630 \mathrm{E}-01$ & 4.6 \\
\hline
\end{tabular}


Table A.9. Ammonia Partial Pressure, Water Partial Pressure, and Calculated Henry's Law Constants for 2.50 Molal Sodium Hydroxide Solution Containing 0.643 Molal Aqueous Ammonia

\begin{tabular}{|c|c|c|c|c|}
\hline Temperature, ${ }^{\circ} \mathrm{C}$ & $\begin{array}{l}\text { Total Pressure, } \\
\text { atm. }\end{array}$ & $\begin{array}{l}\text { Water Partial } \\
\text { Pressure, atm. }\end{array}$ & $\begin{array}{l}\text { Ammonia Partial } \\
\text { Pressure, atm. }\end{array}$ & $\begin{array}{l}\text { Henry's Law } \\
\text { Constant, } \\
\text { mole/kg-atm. }\end{array}$ \\
\hline 31.9 & $7.09 \mathrm{E}-02$ & $4.18 \mathrm{E}-02$ & $2.91 \mathrm{E}-02$ & 22.1 \\
\hline 38.1 & $9.33 E-02$ & $5.84 \mathrm{E}-02$ & $3.49 E-02$ & 18.4 \\
\hline 43.1 & $1.18 \mathrm{E}-01$ & $7.57 \mathrm{E}-02$ & $4.26 \mathrm{E}-02$ & 15.1 \\
\hline 48.6 & $1.52 \mathrm{E}-01$ & $9.97 \mathrm{E}-02$ & $5.21 \mathrm{E}-02$ & 12.3 \\
\hline 52.3 & $1.79 \mathrm{E}-01$ & $1.195 \mathrm{E}-01$ & $6.00 \mathrm{E}-02$ & 10.7 \\
\hline 57.6 & $2.25 \mathrm{E}-01$ & $1.536 \mathrm{E}-01$ & 7.13E-02 & 9.0 \\
\hline 61.7 & $2.70 \mathrm{E}-01$ & $1.856 \mathrm{E}-01$ & $8.47 \mathrm{E}-02$ & 7.6 \\
\hline 65.8 & $3.18 \mathrm{E}-01$ & $2.231 \mathrm{E}-01$ & $9.52 \mathrm{E}-02$ & 6.8 \\
\hline 71.1 & $3.90 \mathrm{E}-01$ & $2.814 \mathrm{E}-01$ & $1.087 \mathrm{E}-01$ & 5.9 \\
\hline
\end{tabular}

Table A.10. Ammonia Partial Pressure, Water Partial Pressure, and Calculated Henry's Law Constants for 3.99 Molal Sodium Hydroxide Solution Containing 0.616 Molal Aqueous Ammonia

\begin{tabular}{|c|c|c|c|c|}
\hline Temperature, ${ }^{\circ} \mathrm{C}$ & $\begin{array}{l}\text { Total Pressure, } \\
\text { atm. }\end{array}$ & $\begin{array}{l}\text { Water Partial } \\
\text { Pressure, atm. }\end{array}$ & $\begin{array}{l}\text { Ammonia Partial } \\
\text { Pressure, atm. }\end{array}$ & $\begin{array}{c}\text { Henry's Law } \\
\text { Constant, } \\
\text { molc/kg-atm. }\end{array}$ \\
\hline 27.0 & $6.03 E-02$ & $2.86 \mathrm{E}-02$ & $3.17 \mathrm{E}-02$ & 19.5 \\
\hline 32.0 & $7.61 \mathrm{E}-02$ & $3.80 \mathrm{E}-02$ & $3.81 E-02$ & 16.2 \\
\hline 37.8 & $1.043 \mathrm{E}-01$ & $5.22 E-02$ & $5.22 E-02$ & 11.8 \\
\hline 43.6 & $1.372 \mathrm{E}-01$ & $7.09 \mathrm{E}-02$ & $6.64 \mathrm{E}-02$ & 9.3 \\
\hline 51.3 & $1.826 \mathrm{E}-01$ & $1.047 \mathrm{E}-01$ & $7.80 E-02$ & 7.9 \\
\hline 56.9 & $2.320 \mathrm{E}-01$ & $1.373 \mathrm{E}-01$ & $9.46 \mathrm{E}-02$ & 6.5 \\
\hline 61.6 & $2.820 \mathrm{E}-01$ & $1.713 \mathrm{E}-01$ & $1.106 \mathrm{E}-01$ & 5.6 \\
\hline 66.8 & $3.471 \mathrm{E}-01$ & $2.173 \mathrm{E}-01$ & $1.298 \mathrm{E}-01$ & 4.7 \\
\hline 71.2 & $4.109 E-01$ & $2.642 \mathrm{E}-01$ & $1.468 \mathrm{E}-01$ & 4.2 \\
\hline
\end{tabular}


Table A.11. Ammonia Partial Pressure, Water Partial Pressure, and Calculated Henry's Law Constants for 5.47 Molal Sodium Hydroxide Solution Containing 0.741 Molal Aqueous Ammonia

\begin{tabular}{|c|c|c|c|c|}
\hline Temperature, ${ }^{\circ} \mathrm{C}$ & $\begin{array}{c}\text { Total Pressure, } \\
\mathrm{atm} .\end{array}$ & $\begin{array}{l}\text { Watcr Partial } \\
\text { Pressure, atm. }\end{array}$ & $\begin{array}{l}\text { Ammonia Partial } \\
\text { Pressure, atm. }\end{array}$ & $\begin{array}{c}\text { Henry's Law } \\
\text { Constant, } \\
\text { mole/kg-atm. }\end{array}$ \\
\hline 26.1 & 8.05E-02 & $2.47 \mathrm{E}-02$ & $5.58 \mathrm{E}-02$ & $\begin{array}{l}1 \\
3.3\end{array}$ \\
\hline 32.6 & $1.040 \mathrm{E}-01$ & $3.56 \mathrm{E}-02$ & $6.84 \mathrm{E}-02$ & 10.9 \\
\hline 38.1 & $1.26 \mathrm{E}-01$ & $4.78 \mathrm{E}-02$ & $7.84 \mathrm{E}-02$ & 9.5 \\
\hline 43.9 & $1.60 \mathrm{E}-01$ & $6.46 \mathrm{E}-02$ & $9.56 \mathrm{E}-02$ & 7.8 \\
\hline 50.6 & $2.140 \mathrm{E}-01$ & $9.01 \mathrm{E}-02$ & $1.238 \mathrm{E}-01$ & 6.0 \\
\hline 56.1 & $2.650 \mathrm{E}-01$ & $1.173 \mathrm{E}-01$ & $1.477 \mathrm{E}-01$ & 5.0 \\
\hline 61.9 & $3.226 \mathrm{E}-01$ & $1.534 \mathrm{E}-01$ & $1.692 \mathrm{E}-01$ & 4.4 \\
\hline 66.8 & $3.981 \mathrm{E}-01$ & $1.911 \mathrm{E}-01$ & $2.070 \mathrm{E}-01$ & 3.6 \\
\hline 70.9 & $4.657 \mathrm{E}-01$ & $2.286 \mathrm{E}-01$ & $2.370 \mathrm{E}-01$ & 3.1 \\
\hline
\end{tabular}

Table A.12. Ammonia Partial Pressure, Water Partial Pressure, and Calculated Henry's Law Constants for 6.95 Molal Sodium Hydroxide Solution Containing 0.744 Molal Aqueous Ammonia

\begin{tabular}{|c|c|c|c|c|}
\hline Temperature ${ }^{\circ} \mathrm{C}$ & $\begin{array}{c}\text { Total Pressure, } \\
\text { atm. }\end{array}$ & $\begin{array}{l}\text { Water Partial } \\
\text { Pressure, alm. }\end{array}$ & $\begin{array}{l}\text { Ammonia Partial } \\
\text { Pressure, atm. }\end{array}$ & $\begin{array}{c}\text { Henry's Law } \\
\text { Constant, } \\
\text { mole/kg-atm. }\end{array}$ \\
\hline 27.9 & $1.255 \mathrm{E}-01$ & $2.51 \mathrm{E}-02$ & $1.004 \mathrm{E}-01$ & 7.4 \\
\hline 31.7 & $1.318 \mathrm{E}-01$ & $3.10 \mathrm{E}-02$ & $1.008 \mathrm{E}-01$ & 7.4 \\
\hline 38.2 & $1.688 \mathrm{E}-01$ & $4.40 \mathrm{E}-02$ & $1.248 \mathrm{E}-01$ & 6.0 \\
\hline 43.3 & $2.055 \mathrm{E}-01$ & $5.73 E-02$ & $1.483 \mathrm{E}-01$ & 5.0 \\
\hline 49.1 & $2.520 \mathrm{E}-01$ & $7.65 \mathrm{E}-02$ & $1.755 \mathrm{E}-01$ & 4.2 \\
\hline 53.3 & 2.905.E-01 & $9.37 \bar{E}-02$ & $1.968 \mathrm{E}-01$ & 3.8 \\
\hline 58.7 & $3.455 \mathrm{E}-01$ & $1.208 \mathrm{E}-01$ & $2.247 \mathrm{E}-01$ & 3.3 \\
\hline 64.8 & $4.300 \mathrm{E}-01$ & $1.594 \mathrm{E}-01$ & $2.706 \mathrm{E}-01$ & 2.8 \\
\hline 71.0 & $5.225 \mathrm{E}-01$ & $2.091 E-01$ & $3.134 \mathrm{E}-01$ & 2.4 \\
\hline
\end{tabular}


Appendix B

Simulant Partial Pressure Data 


\section{Appendix B}

\section{Simulant Partial Pressure Data}

Table B.1. Water Partial Pressures for Simulant SY1-SIM-93B (Homogeneous Simulant) Containing 0.000 Molal Aqueous Ammonia

Tempcrature, ${ }^{\circ} \mathrm{C}$

26.7

31.6

37.5

41.9

46.9

51.5

55.9

61.2

66.6

72.1
Water Partial Pressure, atm.

2.62E-02

$3.46 \mathrm{E}-02$

$4.36 \mathrm{E}-02$

5.59E-02

7.34E-02

9.30E-02

$1.14 \mathrm{E}-01$

$1.47 \mathrm{E}-01$

$1.84 \mathrm{E}-0 \mathrm{I}$

2.48E-01

Table B.2. Water Partial Pressures for Simulant SY1-SIM-91A (Slurry) Containing 0.000 Molal Aqueous Ammonia

Temperature, ${ }^{\circ} \mathrm{C}$

26.5

33.2

38.9

44.5

50.1

55.3

60.5

65.3

70.5
Water Partial Pressure, atm.

$1.46 \mathrm{E}-02$

$1.79 \mathrm{E}-02$

$2.57 \mathrm{E}-02$

3.36E-02

4.40E-02

$5.58 \mathrm{E}-02$

7.34E-02

$1.030 \mathrm{E}-01$

1.450E-01

B. 1 
Table B.3. Ammonia Partial Pressures for Simulant SY1-SIM-93B Containing 0.859 Molal Aqueous Ammonia

\begin{tabular}{|c|c|c|c|c|}
\hline Temperature. ${ }^{\circ} \mathrm{C}$ & $\begin{array}{c}\text { Total Pressure, } \\
\text { atm. }\end{array}$ & $\begin{array}{l}\text { Water Partial } \\
\text { Pressure, atm. }\end{array}$ & $\begin{array}{l}\text { Ammonia Partial } \\
\text { Pressure, atm. }\end{array}$ & $\begin{array}{c}\text { Henry's Law } \\
\text { Constant, } \\
\text { mole/kg-atm. }\end{array}$ \\
\hline 27.6 & $6.53 \mathrm{E}-02$ & $2.66 \mathrm{E}-02$ & $3.86 \mathrm{E}-02$ & 22.3 \\
\hline 32.2 & $8.14 \mathrm{E}-02$ & $3.44 \mathrm{E}-02$ & $4.70 \mathrm{E}-02$ & 18.3 \\
\hline 37.3 & $1.024 \mathrm{E}-01$ & $4.53 \mathrm{E}-02$ & $5.70 \mathrm{E}-02$ & 15.1 \\
\hline 43.1 & $1.324 \mathrm{E}-01$ & $6.13 E-02$ & $7.11 \mathrm{E}-02$ & 12.1 \\
\hline 48.9 & $1.670 \mathrm{E}-01$ & $8.20 \mathrm{E}-02$ & $8.77 E-02$ & 9.8 \\
\hline 55.3 & $2.221 \mathrm{E}-01$ & $1.118 \mathrm{E}-01$ & $1.104 \mathrm{E}-01$ & 7.8 \\
\hline 60.8 & $2.738 \mathrm{E}-01$ & $1.444 \mathrm{E}-01$ & $1.294 \mathrm{E}-01$ & 6.6 \\
\hline 65.5 & $3.283 \mathrm{E}-01$ & $1.786 \mathrm{E}-01$ & $1.497 \mathrm{E}-01$ & 5.7 \\
\hline 70.9 & $4.011 \mathrm{E}-01$ & $2.264 \mathrm{E}-01$ & $1.747 \mathrm{E}-01$ & 4.9 \\
\hline
\end{tabular}

Table B.4. Ammonia Partial Pressures for Simulant SY1-SIM-93B Containing 1.519 Molal Aqueous Ammonia

\begin{tabular}{|c|c|c|c|c|}
\hline Temperature, ${ }^{\circ} \mathrm{C}$ & $\begin{array}{l}\text { Total Pressure, } \\
\text { atm. }\end{array}$ & $\begin{array}{l}\text { Watcr Partial } \\
\text { Pressure, atm. }\end{array}$ & $\begin{array}{l}\text { Ammonia Partial } \\
\text { Pressure, atm. }\end{array}$ & $\begin{array}{c}\text { Henry's Law } \\
\text { Constant, } \\
\text { mole/kg-atm. }\end{array}$ \\
\hline 27.7 & $1.000 \mathrm{E}-01$ & $2.68 \mathrm{E}-02$ & 7.32E-02 & 20.8 \\
\hline 32.5 & $1.217 \mathrm{E}-01$ & $3.50 \mathrm{E}-02$ & $8.67 \mathrm{E}-02$ & 17.5 \\
\hline 39.0 & $1.559 \mathrm{E}-01$ & $4.96 \mathrm{E}-02$ & $1.064 \mathrm{E}-01$ & 14.3 \\
\hline 43.8 & $1.862 \mathrm{E}-01$ & $6.35 \mathrm{E}-02$ & $1.227 \mathrm{E}-01$ & 12.4 \\
\hline 49.6 & $2.329 \mathrm{E}-01$ & $8.49 E-02$ & $1.480 \mathrm{E}-01$ & 10.3 \\
\hline 53.6 & $2.796 \mathrm{E}-01$ & $1.031 \mathrm{E}-01$ & $1.766 \mathrm{E}-01^{\circ}$ & 8.6 \\
\hline 59.6 & $3.342 \mathrm{E}-01$ & $1.367 \mathrm{E}-01$ & $1.976 \mathrm{E}-01$ & 7.7 \\
\hline 63.8 & $3.895 \mathrm{E}-01$ & $1.655 \mathrm{E}-01$ & $2.240 \mathrm{E}-01$ & 6.8 \\
\hline 71.7 & $5.111 \mathrm{E}-01$ & $2.343 E-01$ & $2.769 E-01$ & 5.5 \\
\hline
\end{tabular}


Table B.5. Ammonia Partial Pressures for Simulant SY1-SIM-93B Containing 2.228 Molal Aqueous Ammonia

\begin{tabular}{|c|c|c|c|c|}
\hline Temperature, ${ }^{\circ} \mathrm{C}$ & $\begin{array}{c}\text { Total Pressure, } \\
\text { atm. }\end{array}$ & $\begin{array}{l}\text { Water Partial } \\
\text { Pressure, atm. }\end{array}$ & $\begin{array}{l}\text { Ammonia Partial } \\
\text { Pressure, atm. }\end{array}$ & $\begin{array}{c}\text { Constant, } \\
\text { mole/kg-atm. }\end{array}$ \\
\hline 28.0 & $1.303 E-01$ & $2.56 \mathrm{E}-02$ & $1.047 \mathrm{E}-01$ & 21.3 \\
\hline 32.6 & $1.537 \mathrm{E}-01$ & $3.31 \mathrm{E}-02$ & $1.206 \mathrm{E}-01$ & 18.5 \\
\hline 39.1 & $1.943 \mathrm{E}-01$ & $4.70 \mathrm{E}-02$ & $1.473 \mathrm{E}-01$ & 15.1 \\
\hline 43.8 & $2.309 \mathrm{E}-01$ & $6.01 \mathrm{E}-02$ & $1.709 \mathrm{E}-01$ & 13.0 \\
\hline 48.9 & $2.795 \mathrm{E}-01$ & $7.77 \mathrm{E}-02$ & $2.018 \mathrm{E}-01$ & 11.0 \\
\hline 54.3 & $3.378 \mathrm{E}-01$ & $1.011 \mathrm{E}-01$ & $2.367 \mathrm{E}-01$ & 9.4 \\
\hline 59.4 & $4.059 \mathrm{E}-01$ & $1.287 \mathrm{E}-01$ & $2.772 \mathrm{E}-01$ & 8.0 \\
\hline 65.4 & $4.992 \mathrm{E}-01$ & $1.693 \mathrm{E}-01$ & $3.300 \mathrm{E}-01$ & 6.8 \\
\hline 71.7 & $6.147 \mathrm{E}-01$ & $2.234 \mathrm{E}-01$ & $3.913 \mathrm{E}-01$ & 5.7 \\
\hline
\end{tabular}

Table B.6. Ammonia Partial Pressures for Simulant SY1-SIM-93B Containing 3.532 Molal Aqueous Ammonia

\begin{tabular}{|c|c|c|c|c|}
\hline Temperature, ${ }^{\circ} \mathrm{C}$ & $\begin{array}{l}\text { Total Pressure, } \\
\text { atm. }\end{array}$ & $\begin{array}{l}\text { Water Partial } \\
\text { Pressure, atm. }\end{array}$ & $\begin{array}{c}\text { Ammonia Partial } \\
\text { Pressure, atm. }\end{array}$ & $\begin{array}{c}\text { Henry's Law } \\
\text { Constant, } \\
\text { mole/kg-atm. }\end{array}$ \\
\hline 27.3 & $1.681 \mathrm{E}-01$ & $2.62 \mathrm{E}-02$ & $1.420 \mathrm{E}-01$ & 24.9 \\
\hline 32.1 & $1.957 \mathrm{E}-01$ & $3.42 \mathrm{E}-02$ & $1.614 \mathrm{E}-01$ & 21.9 \\
\hline 37.2 & $2.437 \mathrm{E}-01$ & $4.51 \mathrm{E}-02$ & $1.986 \mathrm{E}-01$ & 17.8 \\
\hline 43.2 & $2.855 \mathrm{E}-01$ & $6.16 \mathrm{E}-02$ & $2.239 \mathrm{E}-01$ & 15.8 \\
\hline 49.1 & $3.472 \mathrm{E}-01$ & $8.28 \mathrm{E}-02$ & $2.644 \mathrm{E}-01$ & 13.4 \\
\hline 53.9 & $4.057 \mathrm{E}-01$ & $1.046 \mathrm{E}-01$ & $3.011 \mathrm{E}-01$ & 11.7 \\
\hline 60.0 & $4.976 \mathrm{E}-01$ & $1.392 \mathrm{E}-01$ & $3.584 \mathrm{E}-01$ & 9.9 \\
\hline 65.2 & $5.883 \mathrm{E}-01$ & $1.762 \mathrm{E}-01$ & $4.121 \mathrm{E}-01$ & 8.6 \\
\hline 70.5 & $7.079 \mathrm{E}-01$ & $2.225 \mathrm{E}-01$ & $4.854 \mathrm{E}-01$ & 7.3 \\
\hline
\end{tabular}


Table B.7. Ammonia Partial Pressures for Simulant SY1-SIM-91A Containing 1.274 Molal Aqueous Ammonia

\begin{tabular}{|c|c|c|c|c|}
\hline Temperature ${ }^{\circ} \mathrm{C}$ & $\begin{array}{c}\begin{array}{c}\text { Total Pressure, } \\
\text { atm. }\end{array} \\
\end{array}$ & $\begin{array}{l}\text { Water Partial } \\
\text { Pressure, atm. }\end{array}$ & $\begin{array}{l}\text { Ammonia Partial } \\
\text { Pressure, atm. }\end{array}$ & $\begin{array}{c}\text { Constant, } \\
\text { molc/kg-atm. }\end{array}$ \\
\hline 29.3 & $2.182 \mathrm{E}-01$ & $1.50 \mathrm{E}-02$ & $2.031 \mathrm{E}-01$ & 6.3 \\
\hline 34.6 & $2.386 \mathrm{E}-01$ & $2.04 \mathrm{E}-02$ & $2.182 \mathrm{E}-01$ & 5.8 \\
\hline 41.3 & $2.879 \mathrm{E}-01$ & $2.95 \mathrm{E}-02$ & $2.584 \mathrm{E}-01$ & 4.9 \\
\hline 46.7 & $3.333 \mathrm{E}-01$ & $3.93 E-02$ & $2.940 \mathrm{E}-01$ & 4.3 \\
\hline 51.7 & $3.767 \mathrm{E}-01$ & $5.09 \mathrm{E}-02$ & $3.258 \mathrm{E}-01$ & 3.9 \\
\hline 56.9 & $4.215 \mathrm{E}-01$ & $6.60 \mathrm{E}-02$ & $3.555 \mathrm{E}-01$ & 3.6 \\
\hline 62.1 & $4.938 \mathrm{E}-01$ & $8.49 \mathrm{E}-02$ & $4.090 \mathrm{E}-01$ & 3.1 \\
\hline 67.5 & $5.642 \mathrm{E}-01$ & $1.093 \mathrm{E}-0.1$ & $4.549 \mathrm{E}-01$ & 2.8 \\
\hline 71.5 & $6.241 \mathrm{E}-01$ & $1.312 \mathrm{E}-01$ & $4.929 \mathrm{E}-01$ & 2.6 \\
\hline
\end{tabular}

Table B.8. Ammonia Partial Pressures for Simulant SY1-SIM-91A Containing 2.297 Molal Aqueous Ammonia

\begin{tabular}{|c|c|c|c|c|}
\hline Temperature, ${ }^{\circ} \mathrm{C}$ & $\begin{array}{c}\text { Total Pressure, } \\
\text { atm. } \\
\end{array}$ & $\begin{array}{l}\text { Watcr Partial } \\
\text { Pressurc, atm. }\end{array}$ & $\begin{array}{l}\text { Ammonia Partial } \\
\text { Pressurc, atm. }\end{array}$ & $\begin{array}{c}\text { Henry's Law } \\
\text { Constant, } \\
\text { mole/kg-atm. }\end{array}$ \\
\hline 27.3 & $3.368 \mathrm{E}-01$ & $1.33 \mathrm{E}-02$ & $3.235 \mathrm{E}-01$ & 7.1 \\
\hline 33.6 & $3.921 \mathrm{E}-01$ & $1.92 \mathrm{E}-02$ & $3.729 \mathrm{E}-01$ & 6.2 \\
\hline 39.3 & $4.618 \mathrm{E}-01$ & $2.65 \mathrm{E}-02$ & $4.354 \mathrm{E}-01$ & 5.3 \\
\hline 43.6 & $5.250 \mathrm{E}-01$ & $3.34 \mathrm{E}-02$ & $4.916 \mathrm{E}-01$ & 4.7 \\
\hline 49.0 & $5.993 E-01$ & $4.43 \mathrm{E}-02$ & $5.550 \mathrm{E}-01$ & 4.1 \\
\hline 53.8 & $6.809 \mathrm{E}-01$ & $5.66 \mathrm{E}-02$ & $6.243 E-01$ & 3.7 \\
\hline 59.3 & $7.901 \mathrm{E}-01$ & $7.42 \mathrm{E}-02$ & $7.159 \mathrm{E}-01$ & 3.2 \\
\hline 65.7 & $9.257 \mathrm{E}-01$ & $1.006 \mathrm{E}-01$ & $8.251 \mathrm{E}-01$ & 2.8 \\
\hline
\end{tabular}


Table B.9. Ammonia Partial Pressures for Simulant SY1-SIM-91A Containing 3.305 Molal Aqueous Ammonia

\begin{tabular}{|c|c|c|c|c|}
\hline Temperature ${ }^{\circ} \mathrm{C}$ & $\begin{array}{l}\text { Total Pressure, } \\
\text { atm. }\end{array}$ & $\begin{array}{l}\text { Water Partial } \\
\text { Pressure, atm. }\end{array}$ & $\begin{array}{l}\text { Ammonia Partial } \\
\text { Pressure, atm. }\end{array}$ & $\begin{array}{c}\text { Henry's Law } \\
\text { Constant, } \\
\text { mole/kg-atm. }\end{array}$ \\
\hline 27.3 & $4.224 \mathrm{E}-01$ & $1.33 \mathrm{E}-02$ & $4.089 \mathrm{E}-01$ & 8.1 \\
\hline 32.1 & $4.762 \mathrm{E}-01$ & $1.77 \mathrm{E}-02$ & $4.585 \mathrm{E}-01$ & 7.2 \\
\hline 38.5 & $5.716 \mathrm{E}-01$ & $2.53 \mathrm{E}-02$ & $5.463 \mathrm{E}-01$ & 6.1 \\
\hline 44.3 & $6.795 \mathrm{E}-01$ & $3.47 \mathrm{E}-02$ & $6.448 \mathrm{E}-01$ & 5.1 \\
\hline 47.9 & $7.499 \mathrm{E}-01$ & 4.19E-02 & $7.080 \mathrm{E}-01$ & 4.7 \\
\hline 51.7 & $8.466 \mathrm{E}-01$ & $5.09 E-02$ & 7.957E-01 & 4.2 \\
\hline 55.0 & $9.249 \mathrm{E}-01$ & $6.01 \mathrm{E}-02$ & $8.648 \mathrm{E}-01$ & 3.8 \\
\hline
\end{tabular}


Table B.10. Estimated Aqucous Ammonia Concentrations in Tank 241-SY-101 Wastes as a Function of Temperature and Water Content, Based on Henry's Law Constants Determined for Simulant SY1-SIM-91A

\begin{tabular}{|c|c|c|c|c|c|c|c|}
\hline $\mathrm{T},{ }^{\circ} \mathrm{C}$ & $20 \%$ & $25 \%$ & $30 \%$ & $35 \%$ & $40 \%$ & $45 \%$ & $\underline{50 \%}$ \\
\hline 25 & 0.54 & 0.68 & 0.82 & 0.95 & 1.09 & 1.22 & 1.36 \\
\hline 26 & 0.53 & 0.66 & 0.79 & 0.93 & 1.06 & 1.19 & 1.32 \\
\hline 27 & 0.52 & 0.65 & 0.77 & 0.90 & 1.03 & 1.16 & 1.29 \\
\hline 28 & 0.50 & 0.63 & 0.75 & 0.88 & 1.01 & 1.13 & 1.26 \\
\hline 29 & 0.49 & 0.61 & 0.74 & 0.86 & 0.98 & .1 .10 & 1.23 \\
\hline 30 & 0.48 & 0.60 & 0.72 & 0.84 & 0.96 & 1.08 & 1.20 \\
\hline 31 & 0.47 & 0.58 & 0.70 & 0.82 & 0.93 & 1.05 & 1.17 \\
\hline 32 & 0.46 & 0.57 & 0.68 & 0.80 & 0.91 & 1.03 & 1.14 \\
\hline 33 & 0.44 & 0.56 & 0.67 & 0.78 & 0.89 & 1.00 & 1.11 \\
\hline 34 & 0.43 & 0.54 & 0.65 & 0.76 & 0.87 & 0.98 & 1.08 \\
\hline 35 & 0.42 & 0.53 & 0.64 & 0.74 & 0.85 & 0.95 & 1.06 \\
\hline 36 & 0.41 & 0.52 & 0.62 & 0.72 & 0.83 & 0.93 & 1.03 \\
\hline 37 & 0.40 & 0.50 & 0.61 & 0.71 & 0.81 & 0.91 & 1.01 \\
\hline 38 & 0.39 & 0.49 & 0.59 & 0.69 & 0.79 & 0.89 & 0.99 \\
\hline 39 & 0.39 & 0.48 & 0.58 & 0.67 & 0.77 & 0.87 & 0.96 \\
\hline 40 & 0.38 & 0.47 & 0.56 & 0.66 & 0.75 & 0.85 & 0.94 \\
\hline 41. & 0.37 & 0.46 & 0.55 & 0.64 & 0.74 & 0.83 & 0.92 \\
\hline 42 & 0.36 & 0.45 & 0.54 & 0.63 & 0.72 & 0.81 & 0.90 \\
\hline 43 & 0.35 & 0.44 & 0.53 & 0.62 & 0.70 & 0.79 & 0.88 \\
\hline 44 & 0.34 & 0.43 & 0.52 & 0.60 & 0.69 & 0.77 & 0.86 \\
\hline 45 & 0.34 & 0.42 & 0.50 & 0.59 & 0.67 & 0.76 & 0.84 \\
\hline 46 & 0.33 & 0.41 & 0.49 & 0.58 & 0.66 & 0.74 & 0.82 \\
\hline 47 & 0.32 & 0.40 & 0.48 & 0.56 & 0.64 & 0.72 & 0.80 \\
\hline 48 & 0.31 & 0.39 & 0.47 & 0.55 & 0.63 & 0.71 & 0.79 \\
\hline 49 & 0.31 & 0.38 & 0.46 & 0.54 & 0.62 & 0.69 & 0.77 \\
\hline 50 & 0.30 & 0.38 & 0.45 & 0.53 & 0.60 & 0.68 & 0.75 \\
\hline 51 & 0.29 & 0.37 & 0.44 & 0.52 & 0.59 & 0.66 & 0.74 \\
\hline 52 & 0.29 & 0.36 & 0.43 & 0.51 & 0.58 & 0.65 & 0.72 \\
\hline 53 & 0.28 & 0.35 & 0.42 & 0.49 & 0.57 & 0.64 & 0.71 \\
\hline 54 & 0.28 & 0.35 & 0.41 & 0.48 & 0.55 & 0.62 & 0.69 \\
\hline 55 & 0.27 & 0.34 & 0.41 & 0.47 & 0.54 & 0.61 & 0.68 \\
\hline 56 & 0.27 & 0.33 & 0.40 & 0.46 & 0.53 & 0.60 & 0.66 \\
\hline 57 & 0.26 & 0.32 & 0.39 & 0.45 & 0.52 & 0.58 & 0.65 \\
\hline 58 & 0.25 & 0.32 & 0.38 & 0.45 & 0.51 & 0.57 & 0.64 \\
\hline 59 & 0.25 & 0.31 & 0.37 & 0.44 & 0.50 & 0.56 & 0.62 \\
\hline 60 & 0.24 & 0.31 & 0.37 & 0.43 & 0.49 & 0.55 & 0.61 \\
\hline 61 & 0.24 & 0.30 & 0.36 & 0.42 & 0.48 & 0.54 & 0.60 \\
\hline 62 & 0.24 & 0.29 & 0.35 & 0.41 & 0.47 & 0.53 & 0.59 \\
\hline 63 & 0.23 & 0.29 & 0.35 & 0.40 & 0.46 & 0.52 & 0.58 \\
\hline 64 & 0.23 & 0.28 & 0.34 & 0.40 & 0.45 & 0.51 & 0.56 \\
\hline 65 & 0.22 & 0.28 & 0.33 & 0.39 & 0.44 & 0.50 & 0.55 \\
\hline 66 & 0.22 & 0.27 & 0.33 & 0.38 & 0.43 & 0.49 & 0.54 \\
\hline 67 & 0.21 & 0.27 & 0.32 & 0.37 & 0.43 & 0.48 & 0.53 \\
\hline 68 & 0.21 & 0.26 & 0.31 & 0.37 & 0.42 & 0.47 & 0.52 \\
\hline 69 & 0.21 & 0.26 & 0.31 & 0.36 & 0.41 & 0.46 & 0.51 \\
\hline 70 & 0.20 & 0.25 & 0.30 & 0.35 & 0.40 & 0.45 & 0.50 \\
\hline
\end{tabular}




\section{Appendix C}

Surface Tension Results 


\section{Appendix C}

\section{Surface Tension Results}

Table C.1. Surface Tension of Sodium Hydroxide Solutions

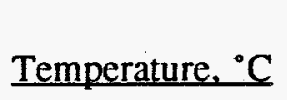

6.3

10.5

21.9

30.8

41.4

50.0

60.0

70.0

79.3
0.0 Wcight Percent

$\mathrm{NaOH}$

75.5

76.1

73.1

71.9

69.4

68.8

67.6

64.6

61.6

\begin{tabular}{ccccc} 
& $\begin{array}{c}2.72 \text { Weight Pcrcent } \\
\text { TaOH }\end{array}$ & $\begin{array}{c}5.88 \text { Weight Pcrcent } \\
\text { NaOH }\end{array}$ & $\begin{array}{c}16.7 \text { Weight Percent } \\
\text { NaOH }\end{array}$ \\
\cline { 2 - 2 } 10.0 & 75.3 & 77.6 & 85.7 \\
20.0 & 75.3 & 76.5 & 83.4 \\
30.0 & 71.3 & 74.8 & 82.3 \\
40.0 & 70.2 & 71.9 & 80.0 \\
50.0 & 69.1 & 71.4 & 77.7 \\
60.0 & 67.3 & 68.5 & 74.9 \\
70.0 & 65.1 & 66.2 & 73.7 \\
80.0 & 62.8 & 65.1 & 72.0
\end{tabular}

C. 1 
Table C.2. Surface Tension of Sodium Nitrate Solutions

\section{Temperature ${ }^{\circ} \mathrm{C}$}

6.3

10.5

21.9

30.8

41.4

50.0

60.0

70.0

79.3

Temperature, ${ }^{\circ} \mathrm{C}$

10.0

20.0

30.0

40.0

50.0

60.0

70.0

80.0

Temperature, ${ }^{\circ} \mathrm{C}$

10.0

20.0

30.0

40.0

50.0

60.0

70.0

80.0
0.0 Weight Percent

$\mathrm{NaNO}_{3}$

75.5

76.1

73.1

71.9

69.4

68.8

67.6

64.6

61.6
0.085 Wcight Percent 5.89 Weight Percent $\mathrm{NaNO}_{3}$

74.3

72.5

71.3

70.1

68.3

66.5

63.5

62.9

14.5 Weight Percent $\mathrm{NaNO}_{3}$

78.3

74.8

73.7

70.3

69.1

67.4

65.7

60.6 $\mathrm{NaNO}_{3}$

74.2

73.1

70.8

70.2

69.6

69.1

64.5

62.8
29.8 Wcight Percent $\mathrm{NaNO}_{3}$

81.8

79.5

78.4

73.3

69.9

67.6

65.9
76.7
7.84 Weight Percent $\mathrm{NaNO}_{3}$

75.9

73.6

71.9

70.2

67.9

67.4

65.1

63.4
37.3 Weight Percent $\mathrm{NaNO}_{3}$

80.7

79.0

77.3

76.2

73.4

71.6

69.4

67.7 
Table C.3. Surface Tension of Homogencous Waste Simulant SY1-SIM-93B

\begin{tabular}{|c|c|c|c|}
\hline Temperature, ${ }^{\circ} \mathrm{C}$ & $\begin{array}{c}0.0 \text { Weight Percent } \\
\text { Ammonia }\end{array}$ & $\begin{array}{l}1.0 \text { Weight Percent } \\
\text { Ammonia }\end{array}$ & $\begin{array}{r}2.0 \text { Weight } P \\
\text { Ammoni }\end{array}$ \\
\hline 30.0 & 82.9 & 78.2 & 75.0 \\
\hline 40.0 & 80.5 & 78.2 & 75.0 \\
\hline 50.0 & 79.4 & 76.1 & 73.9 \\
\hline 60.0 & 76.1 & 75.0 & 72.8 \\
\hline
\end{tabular}

*units are dynes/cm; the average standard deviation from 4 or more determinations for cach condition is 1.5 dynes $/ \mathrm{cm}$.

Table C.4. Surface Tension of Heterogencous Waste Simulant SY1-SIM-91A

\begin{tabular}{|c|c|c|c|}
\hline Temperature, ${ }^{\circ} \mathrm{C}$ & $\begin{array}{c}0.0 \text { Weight Percent } \\
\text { Ammonia }\end{array}$ & Temperature, ${ }^{\circ} \mathrm{C}$ & $\begin{array}{l}1.0 \text { Weight Percent } \\
\text { Ammonia } \\
\end{array}$ \\
\hline 24.7 & 108.2 & 29.7 & 80.2 \\
\hline 29.6 & 106.2 & 39.6 & 72.8 \\
\hline 39.8 & 99.9 & 49.5 & 66.5 \\
\hline 50.1 & 96.8 & 59.9 & 63.3 \\
\hline 59.7 & 95.7 & 69.9 & 64.4 \\
\hline 69.5 & 97.8 & & \\
\hline 79.7 & 88.5 & & \\
\hline
\end{tabular}

*units are dynes $/ \mathrm{cm}$; the average standard deviation from 4 or more determinations for each condition is $1.5 \mathrm{dynes} / \mathrm{cm}$. 
Table C.5. Surface Tension of Heterogencous Waste Simulant SY1-SIM-93B with 1.5 Weight Percent TOC from Organics

$\begin{array}{cccc}\text { Temperature }{ }^{\circ} \mathrm{C} & \text { No Organics } & \text { Sodium Citrate } & \begin{array}{c}\text { Sodium Formate } \\$\cline { 2 - 3 } 23.0\end{array} \\ 30.0 & 82.9 & 84.6 & 83.3 \\ 40.0 & 80.5 & 83.6 & 86.5 \\ 50.0 & 79.4 & 80.3 & 80.2 \\ 60.0 & 76.1 & 80.3 & 70.6 \\ 70.0 & & & 74.9 \\ & & & 73.8 \\ \text {$Temperature }{ }^{\circ} \mathrm{C} & \text { Glycine } & \text { EDTA } & \\ 23.0 & & & \text { HEDTA } \\ 30.0 & 81.2 & 82.5 & \\ 40.0 & 83.3 & 81.4 & 81.2 \\ 50.0 & 82.3 & 80.3 & 79.2 \\ 60.0 & 79.1 & 79.3 & 78.0 \\ 70.0 & 78.0 & 80.3 & 75.9 \\ & 72.7 & 76.0 & 74.9\end{array}$

*units are dynes/cm; the avcrage standard deviation from 4 or more determinations for each condition is 1.5 dynes $/ \mathrm{cm}$.

Table C.6. Surface Tension of Hetcrogencous Waste Simulant SY1-SIM-93B Using Different Bubble Gases

$\begin{array}{cr}\text { Gas } & \text { Temperatur } \\ & \\ \mathrm{N}_{2} & 23.2 \\ \mathrm{O}_{2} & 23.1 \\ \mathrm{H}_{2} & 23.6 \\ \mathrm{~N}_{2} \mathrm{O} & 23.6 \\ \mathrm{CH}_{4} & 23.6\end{array}$

*units are dynes/cm; the average standard deviation from 4 or more detcrminations for cach condition is $1.5 \mathrm{dynes} / \mathrm{cm}$. 


\section{Distribution}

No. of

Copies

Offsite

12 DOE/Office of Scientific and Technical Information

C. S. Abrams

1987 Virginia

Idaho Falls, ID 83404

S. Agnew

Los Alamos National Laboratory

MS-C345, Group INC-4

P.O. Box 1664

Los Alamos, NM 87545

J. Antizzo

U.S. Department of Energy

EM-351

Trevion II

Washington, DC 20585-0002

K. Bandyopadhyay

Building 129

Brookhaven National Laboratory

Upton, NY 11973

E. K. Barefield

225 North Avenue

Boggs Chemistry Building

Georgia Institute of

Technology

Atlanta, GA 30332

N. E. Bibler

Westinghouse Savannah River

Bldg. 773A, Room 108

Aiken, SC 29802

Michelle Broida

ER-72, G-155, GTN

U.S. Department of Energy

19901 Germantown Rd.

Germantown, MD 20874
No. of

Copies

P. Byms

U.S. Department of Energy

EM-35

Trevion II

Washington, DC 20585-0002

D. O. Campbell

Oak Ridge National Laboratory

P.O. Box 2008, MS 6268

Oak Ridge, TN 37831-6268

F. N. Carlson

6965 North, 5th West

Idaho Falls, ID 83401

G. R. Choppin

Department of Chemistry B-164

Florida State University

Tallahassee, FL 32306

E. D. Collins

Oak Ridge National Laboratory

P.O. Box 2008

7930, MS-6385

Oak Ridge, TN 37831-6385

P. d'Entremont

Westinghouse Savannah River

P.O. Box 616, Bldg. 703-H

Aiken, SC 29802

R. Daniels

SAIC

20300 Century Blvd.

2nd Floor

Germantown, MD 20874

J. N. Edwards

Los Alamos National Laboratory

P.O. Box 1663

Los Alamos, NM 87545

Distr.1 
No. of

Copies

M. First

295 Upland Avenue

Newton Highlands, MA 02161

C. Grelecki

Hazards Research Corporation

200 Valley Rd, Suite 301

Mt. Arlington, 07856

E. J. Hart

2115 Hart Road

Port Angeles, WA 98362

P. Hogroian

SAIC

20300 Century Blvd., 2nd Floor

Germantown, MD 20874

E. P. Horwitz

Chemistry Division

Argonne National Laboratory

Argonne, IL 60439

A. Hoskins

WINCO, MS-5217

P.O. Box 4000

Idaho Falls, ID 83403-4000

B. S. Hudson

Lawrence Livermore National

Laboratory, L-221

P.O. Box 808

Livermore, CA 94550

M. S. Kazimi

Room 24-102

77 Massachusetts Avenue

Cambridge, MA 02139

P. Kiang

BDM, Trevion I, Suite 300

12850 Middlebrook Road

Germantown, MD 20874

L. Kovach

NUCON

P.O. Box 29246

Columbus, $\mathrm{OH} 43229$
No. of

Copies

W. L. Kubic, Jr.

Los Alamos National Laboratory

Technology and Safety Assessment Division

TSA-6, Engineering Safety Analysis, MS K557

Los Alamos, NM 87545

B. R. Kowalsik

Chemistry Dept. BG-10

University of Washington

Scattle, WA 98195

T. S. Kress

P.O. Box 2009

MS 8088, Building 9108

Oak Ridge, TN 37381

T. E. Larson

Los Alamos National

Laboratory, M-1

MS C-920, P.O. Box 1663

Los Alamos, NM 87545

C. L. Liotta

225 North Avenue

Boggs Chemistry Building

Georgia Institute of Technology

Atlanta, GA 30332

D. Meisel

Argonne National Laboratory

9700 South Cass Avenue

Argonne, IL 60439

H. M. Newman

225 North Avenue

Boggs Chemistry Building

Georgia Institute of Technology

Atlanta, GA 30332

C. O'Dell

U.S. Department of Energy

EM 36

Trevion II

Washington, DC 20585-0002 
No. of

Copies

D. T. Oakley

Los Alamos National Laboratory

University of California, Suite 310

409 12th Street, SW

Washington, DC 20024-2188

F. L. Parker

Vanderbilt University

P.O. Box 1596, Station B

Nashville, TN 37235

D. Pepson

U.S. Department of Energy

EM 36

Trevion II

Washington, DC 20585-0002

D. Ploetz

West Valley Nuclear Services Co.

P.O. Box 191, MS 305

West Valley, NY 14171-0191

G. Powers

Design Science Inc.

163 Witherow Road

Sewickely, PA 15143

M. Reich

Building 129

Brookhaven National Laboratory

Upton, NY 11973

M. R. Riches

ER-74, G-141, GTN

U.S. Department of Energy

19901 Germantown Rd.

Germantown, MD 20874

G. A. Russell

Department of Chemistry

Iowa State University

Ames, IA 50011-3111

J. Saveland

SAIC

20300 Century Blvd., 2nd Floor

Germantown, MD 20874

G. E. Schmauch

Air Products \& Chemicals, Inc.

7201 Hamilton Blvd.

Allentown, PA 18195-1501
No. of

Copies

\author{
A. Schneider \\ Massachusetts Institute of Technology \\ Department of Nuclear Engineering \\ Room 24-108 \\ 77 Massachusetts Avenue \\ Cambridge, MA 02139
}

W. W. Schulz

727 Sweetleaf Drive

Wilmington, DE 19808

B. Schutte

EG\&G Idaho, Inc.

P.O. Box 1625

Idaho Falls, ID 83415-3940

D. D. Siemer

WINCO

IRC, MS 2207

Idaho Falls, ID 83403

S. E. Slezak

Sandia National Laboratories, Division 6463

P.O. Box 5800

Albuquerque, NM 87185

L. Stock

Chemistry Division

Argonne National Laboratory

Argonne, IL 60439

H. Sullivan

Los Alamos National

Laboratory, N-6, MS-K557

P.O. Box 1664

Los Alamos, NM 87545

H. Sutter

SAIC

20300 Century Blvd., 2nd Floor

Germantown, MD 20874

T. Temple

U.S. Department of Energy,

Bldg. 703-H/115

P.O. Box A

Aiken, SC 29801 
PNL-10173

UC-600

No. of Copies

W. J. Thomson

Department of Chemical Engineering

Washington State University

Pullman, WA 99164

J. Tseng

U.S. Department of Energy

EM-36

Trevion II

Washington, DC 20585-0002

E. Tuthill

Brookhaven National Laboratory

Upton, NY 11973

A. S. Veletsos

5211 Paisley

Houston, TX 77096

G. B. Wallis

Thayer School of Engineering

Darmouth College

Hanover, NH 03755

H. Walter

U.S. Department of Energy

EM-343

Trevion II

Washington, DC 20585-0002

M. Walter

U.S. Department of Energy

EM-35

Trevion II

Washington, DC 20845-0002

G. Woodall

U.S. Department of Energy, MS-1139

785 DOE Place

Idaho Falls, ID 83402

\section{ONSITE}

\section{DOE Richland Operations Office}

R. F. Christensen

A4-02

R. E. Gerton

A5-21

G. Rosenwald

A5 -21

B. J. Tucker

Reading Room
No. of

Copies

29 Westinghouse Hanford Company

J. H. Appel

S4-58

R. P. Anantatmula

R2-11

H. Babad

B2-15

D. B. Bechtold

G. L. Borsheim

T6-50

N. S. Cannon

H5-27

R. J. Cash

L6-38

B3-68

K. A. Gasper

B3-68

D. L. Herting

J. D. Hopkins

T6-50

J. Jewett

R2-08

T6-50

G. D. Johnson (5)

L5-03

N. W. Kirch

R2-11

$\mathrm{HO}-34$

R2-78

J. W. Lentsch

H5-32

R. M. Marusich

R2-78

N. G. McDuffie

B 1-58

M. A. Payne

R2-50

J. C. Person

D. A. Reynolds

T6-50

R2-11

M. H. Shannon

B $1-35$

D. J. Sherwood

R2-78

D. D. Stepnewski

N1-31

R. J. Van Vleet

H4 -63

\section{Pacific Northwest Laboratory}

R. T. Allemann

K5-19

Z. I. Antoniak

K7-15

R. M. Bean

J. W. Brothers (5)

P8-08

K5-22

S. A. Bryan

P7-35

L. L. Burger

P7-25

D. M. Camaioni

K2-38

J. A. Campbcll

P8-08

J. B. Colson

K5-10

S. C. Goheen

P8-08

R. J. Hall

R. T. Hallen

J. D. Husdon

K $1-78$

P8-38

B. M. Johnson, Jr.

K7-15

K5-02

D. K. Lemon

K2-28

G. B. Mellinger

P7-18

J. D. Norton (10)

K2-44

L. G. Morgan

P8-07

L. R. Pederson (10)

K2-44

W. D. Samuels 
PNL-10173

UC-600

No. of

Copies

R. D. Scheele

G. F. Schiefelbein

C. W. Stewart

D. M. Strachan

R. W. Stromatt

D. S. Trent
No. of

Copies

H. H. Van Tuyl

P7-22

P7-25

P8-38

K7-15

K2-44

P7-22

K1-82
B. M. Wise

T. W. Wood

Publishing Coordination

Technical Report Files (5)
K2-12

K6-47

K1-06 